\title{
MATEJKOWSKIE STUDIA PIECZECI PRZECHOWYWANYCH W ARCHIWUM KLASZTORNYM W MOGILE. GENEZA
}

\section{Streszczenie}

Rysunki Jana Matejki przedstawiające pieczęcie przechowywane w Archiwum Klasztoru Cystersów w Mogile stanowią odzwierciedlenie stanu historycznej świadomości, potrzeb kulturowych Polaków w XIX wieku oraz modelu historyzmu wypracowanego w Galicji w połowie XIX wieku. Są świadectwem polskiej recepcji XVII-wiecznej erudycyjnej historiografii, która, będąc znakiem lokalnego patriotyzmu, nadawała wartość lokalnemu dziedzictwu kultury materialnej i włączała go w koncepcję światowej historii, a w XIX wie$\mathrm{ku}$ - także w koncepcję narodowych i światowych dziejów cywilizacji. Tło analiz stanowią poglądy historiograficzne, kolekcjonerskie i kulturowe kształtujące działania i warsztat artystyczny malarza historycznego w XIX wieku. Podkreślono te, które mogły mieć wpływ na percepcję pieczęci przez Jana Matejkę. Kluczową rolę odgrywają w tym procesie zagadnienia poszerzenia pola semantycznego przedmiotów wytworzonych w ubiegłych stuleciach, którym - u progu XIX stulecia - nadano status pamiątki i chętnie gromadzono w kolekcjach, a które stanowiły jednocześnie, jak pieczęcie, źródło wiedzy historycznej rozumianej w sposób erudycyjny, a więc nie tylko jako nośnik informacji o datach, postaciach i wydarzeniach, ale także o strojach, militariach, kulturze materialnej i obyczajach, co w XIX wieku stało się obiektem zainteresowań malarzy historycznych.

Analizy rysunków Jana Matejki ujawniają rozległość percepcji pojedynczych egzemplarzy średniowiecznych pieczęci także w zakresie estetycznym, plastycznym i stylowym, gdyż ostatecznym celem malarza nie było jedynie odtworzenie wyglądu pieczęci, ale historyczna rekonstrukcja i historiozoficzna ocena przeszłości. Podkreślone zostały różnice między inwentaryzatorskim postrzeganiem wizerunków pieczęci, a postrzeganiem sumującym wyżej wy-

\footnotetext{
* Barbara Ciciora - dr historii sztuki; adiunkt w Instytucie Historii Sztuki i Kultury; Uniwersytet Papieski Jana Pawła II w Krakowie; e-mail: barbara.ciciora@upjp2.edu.pl

https://orcid.org/0000-0002-7766-4046
} 
mienione determinanty pracy artysty z plastycznym, zindywidualizowanym typem jego wypowiedzi twórczej, który w przypadku studiów Jana Matejki nabrał dodatkowo charakteru analitycznych badań pieczęci jako wizualnych fragmentów źródeł historycznych.

Słowa kluczowe: Jan Matejko; rysunek; rysunki pieczęci; sfragistyka; malarstwo historyczne; kolekcjonerstwo XIX wieku

Rysunki Jana Matejki przedstawiające pieczęcie przechowywane w Archiwum Klasztoru Cystersów w Mogile stanowią odzwierciedlenie stanu historycznej świadomości, potrzeb kulturowych Polaków w XIX wieku oraz modelu historyzmu wypracowanego w Galicji w połowie XIX wieku. Są świadectwem polskiej recepcji XVII-wiecznej erudycyjnej historiografii, która, będąc znakiem lokalnego patriotyzmu, nadawała wartość lokalnemu dziedzictwu kultury materialnej i włączała go w koncepcję światowej historii ${ }^{1}$, a w XIX wieku - także w koncepcję narodowych i światowych dziejów cywilizacji. Zrozumieniu niuansów semantycznych, które cechują rysunki wybitnego malarza historycznego, służy ukazanie ich na tle nowożytnych badań historycznych, sfragistycznych oraz praktyk i celów kolekcjonerskich, dzięki którym wiedza o historii lokalnej stawała się podstawą formowania struktury wyobrażania i przedstawiania historii narodowej. Celem artykułu nie jest pobieżny zarys historii sfragistyki, ale wyeksponowanie tych jej aspektów, do których sięgał Jan Matejko i środowisko krakowskich starożytników współdziałające z nim przy kwerendach źródłowych i tworzeniu specyficznej, typowej dla Matejki, koncepcji historyzmu ${ }^{2}$. Matejkowskie rysunki pieczęci zachowanych w archiwum klasztornym w Mogile stanowią grupę łatwą do wyodrębnienia i opracowania pod względem treści ideowych. Jednocześnie związane z nimi zagadnienia plastyczne i artystyczne są typowe także dla innych studiów pieczęci wykonywanych przez malarza w innych zbiorach Krakowa ${ }^{3}$.

W celu zrozumienia skali zaangażowania malarzy XIX wieku w poszukiwania historycznych źródeł dla własnych celów artystycznych należy spojrzeć na zmiany w postrzeganiu historii, które zaszły w XVII wieku. Krytyka pisarstwa historycznego, jaka przetoczyła się wówczas przez Europę, zmieniła jego dotychczasowy profil i skłoniła historyków do szerszego wykorzystania świadectw przeszłości zgromadzonych w licznych europejskich archiwach i kolekcjach. Historycy musieli zmierzyć się z zarzutami przedstawicieli nauk ścisłych i filozofów, którzy krytycznie oceniając dorobek XVI-wiecznej i wcześniejszej historiografii twierdzili, iż powstały wówczas obraz historii nie jest prawdziwy, ponieważ są to bajki pisane przez humanistów ku uciesze czytelników. Bernard de Fontenel-

${ }^{1}$ K. Pomian, Zbieracze i osobliwości. Paryż-Wenecja, XVI-XVIII wiek, Gdańsk 2012, s. 118125.

${ }^{2}$ Szersze opracowanie zarysowanej tu problematyki zostanie przedstawione w przygotowywanej drugiej części artykułu.

${ }^{3}$ O szerokim rozumieniu ,zbiorów pieczęci” zob. Z. Piech, Zbiory pieczęci jako przedmiot badań sfragistycznych, w: Zbiory pieczęci w Polsce, red. Z. Piech, W. Strzyżewski, Warszawa 2009, s. 7-30. 
le wsławił się opinią, iż historia to „zmyślenie uznane za prawdę”, libertyni zaś twierdzili, że jest ona niepewna i fałszywa, nikczemna, pełna pochlebstw dla możnych, a jeśli warto ją czytać, to nie po to, by poznać fakty, ale po to, by zobaczyć, jak są interpretowane przez różnych ludzi, różne partie i narody ${ }^{4}$. Tak druzgocąca recenzja historiografii wywołała reakcję części ówczesnych intelektualistów, analitycznie i krytycznie oceniających opinie współczesnych. Uznali oni, że

poddawaną w wątpliwość historyczną prawdę należy zrewaloryzować na drodze krytycznej weryfikacji będącej podstawą wszelkiej dziejopisarskiej narracji wiedzy o historycznych faktach ${ }^{5}$.

Niezwykle skutecznym, bo politycznym, katalizatorem rewaloryzacji pozycji historii wśród nauk stała się dyskusja toczona we Francji w ostatniej ćwierci XVII wieku wokół problemu kwestionowania wyższości klasycznej starożytności nad współczesnością Ludwika XIV, znana jako querelle des Anciens et des Modernes. Charles Perrault, wiodący w walce o nowoczesność, i jemu pokrewni autorzy, odwrót od tradycji humanistycznej skierowali nie w stronę uniwersalizmu lub racjonalizmu de Fontenell'a, ale ku zagadnieniom narodowym. Król Słońce miał zamiar wykorzystać wykreowany w związku z dyskusją i oparty na bazie kulturowej twór, zwany Le Siècle de Louis le Grand, do swych celów politycznych: oto Francja staje się obecnie państwem wiodącym w Europie pod każdym względem, także politycznym, a ściśle biorąc - dominacji politycznej popartej ostatecznie agresją militarną wobec państw ościennych ${ }^{6}$. Ludwik, traktując poważnie i sumiennie swą własną kreację l'État c'est moi, był zainteresowany rozwojem koncepcji na nowo zdefiniowanej, nowoczesnej tożsamości Francuzów ${ }^{7}$. Do jej sformowania stało się niezbędne właściwe, nowoczesne opracowanie przeszłości. Tak jasno i klarownie sformułowane cele polityczne doprowadziły do znanej już sytuacji, w której jeszcze za życia Króla Słońce zaczęły powstawać publikacje typu Antiquité de la nation et de la langue des Celtes, autrement appellez Gaulois Paula Yvesa Perrona, której autor przekonywał, że Galowie byli narodem starszym i potężniejszym niż Rzymianie ${ }^{8}$. Niestety, wysiłki tego rodzaju pisarzy historycznych i piewców średniowiecznej przeszłości nie odniosły skutecznego politycznego rezultatu opartego na przekształceniu świadomości elit społecznych. Nowej wizji przeszłości zabrakło przekonującej wizualizacji zarówno w obszarze literatury, dramatu, jak i sztuk plastycznych. Brak równie przekonujących, bo opartych o krytyczną wiedzę, informacji na temat kształtu odległych czasów średniowiecza ${ }^{9}$.

\footnotetext{
${ }^{4}$ A. Grabski, Dzieje historiografii, Poznań 2006, s. 275-276.

${ }^{5}$ Tamże, s. 280.

${ }^{6}$ Por. K. Secomska, Spór o starożytność. Problemy malarstwa w „Paralelach” Perrault, Warszawa 1991, s. 70-73.

${ }^{7} \mathrm{Z}$ równą powagą i konsekwencją dążył do tego, by już nie Rzym, ale Paryż i Wersal zostały stolicą świata, co niewątpliwie stało się już za jego życia. Natomiast w XVIII w. nastąpiło ostateczne „translatio studii” i Paryż został głównym ośrodkiem promieniowania wiedzy i sztuki. Tamże, s. 4.

${ }^{8}$ P.Y. Perron, Antiquité de la nation et de la langue des Celtes, autrement appellez Gaulois, Paris 1703, za: Secomska Spór o starożytność, s. 73 i 333-335.

${ }^{9}$ Secomska, Spór o starożytność, s. 73.
} 


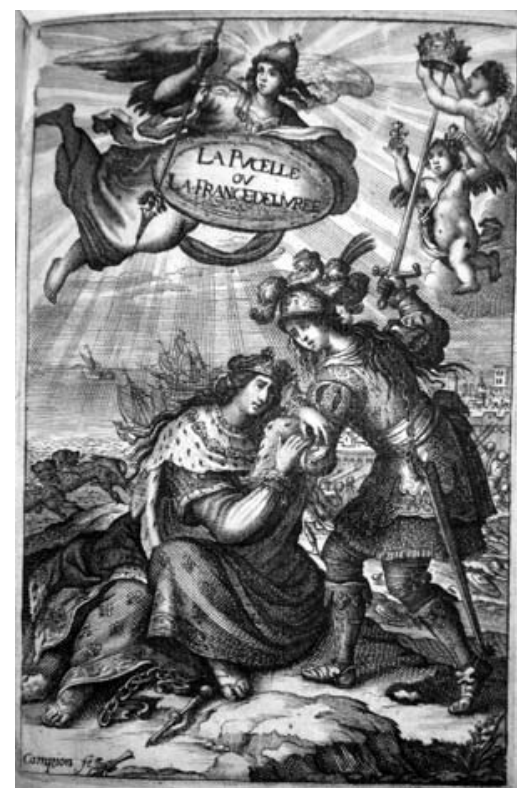

Il.1. Abraham Bosse wg Claude Vignon'a, Joanna d'Arc przybywa na ratunek królowi Francji, karta tytułowa poematu Jeana Chapelain'a, La Pucelle, ou la France délivrée. Poème héröque, Paris 1656.

Część francuskich historyków, nie czując potrzeby kreowania pisarstwa historycznego $\mathrm{w}$ związku $\mathrm{z}$ aktualnymi potrzebami politycznymi, a zdając sobie sprawę z zarzutów stawianych współcześnie ich dyscyplinie, rozpoczęła intensywne, wnikliwe i bardzo krytyczne badania własnej przeszłości, przeszłości narodowej, znajdując jej korzenie nie w antyku, co w XVI wieku nadawało wartość narodom europejskim, ale w okresie panowania przedrzymskich Gallów oraz wczesnośredniowiecznych Merowingów i Karolingów. Bezcenne stały się już nie tylko dokumenty, ale także inne świadectwa kultury materialnej. Francuskim historykom w poszukiwaniu korzeni własnych narodów nie zamierzali ustąpić pola historycy innych nacji ${ }^{10}$. Paul Hazard komentował:

całe rzesze erudytów przykładały się pracowicie do niewdzięcznych zajęć: wydawania tekstów, odcyfrowywania dokumentów, oskrobywania kamieni, czyszczenia monet. Całe odważne, zapalone rzesze: mrowisko, które miało swoich rzemieślników, a nawet wojowników. Ci gorliwi pracownicy, pasjonujący się swoją ciężka pracą, dążyli do ustalenia rzeczy pewnych - doniosłych lub drobnych, ale niewzruszonych. Pragnęli bez pochopnych interpretacji, bez uprzedzeń, bez zniekształcenia przez sztukę wydobyć rzeczy solidne, ustalone raz na zawsze ${ }^{11}$.

Działania te stworzyły podstawę do rozwoju nauk pomocniczych historii, jak paleografia, chronologia, epigrafika, leksykografia i dyplomatyka, której zna-

${ }^{10}$ Tamże, s. 86-89.

${ }^{11}$ Cyt. za Grabski, Dzieje historiografii, s. 284. 
komitym osiągnięciem był traktat De re diplomatica libri VI Jeana Mabillona, wydany w 1681 roku, w którym zostały opisane zasady pracy z dokumentami średniowiecznymi aktualne do dziś ${ }^{12}$.

Wykorzystanie średniowiecza w poznawaniu historii własnego kraju opartym na pielęgnowaniu uczuć patriotycznych oraz dumy z lokalnej przeszłości miało miejsce także we Włoszech, ale wcześniej niż we Francji, bo już w latach 20. XVII wieku ${ }^{13}$. Istotna różnica między Północą a Południem polega na tym, że mieszkańcy włoskich regionów i tamtejszych miast, nawet politycznie niesamodzielnych i podporządkowanych, np. zależnych od Wenecji, pielęgnowali kult przeszłości swego miasta, jako wyraz ciągłości istnienia na tym terenie od czasów imperium stworzonego przez Rzym, a średniowiecze traktowali jako jeden z ważnych etapów łączących rzymską przeszłość z nowożytną, odrodzoną świetnością. Co prawda, historia średniowieczna miała dla nich znaczenie tylko jako historia lokalna, gdyż do XVII wieku historię powszechną utożsamiano z historią starożytną, jednak także historia lokalna, traktowana patriotycznie, miała szansę na utrwalenie $\mathrm{w}$ tej powszechnej dzięki obiektom z okresu porzymskiego, które przetrwały w regionie i świadczyły o ciągłości historii miejsca oraz o urodzonych tu wybitnych osobistościach. O ile w XVII wieku akceptowanym powszechnie źródłem wiedzy o historii lokalnej były ryte na kamieniach inskrypcje, o tyle wraz z rozwojem historii erudycyjnej, opartej na krytycznej weryfikacji dokumentów źródłowych i dorobku pisarzy historycznych oraz na upowszechniającym się właśnie poznaniu i wykorzystaniu innych nośników informacji pisanych - zakres źródeł wiedzy został poszerzony. Od lat 20. XVIII wieku do zainteresowań historycznych - a szerzej, antykwarycznych i kolekcjonerskich - włączono także zabytki średniowiecznej kultury materialnej, m.in. pieczęcie ${ }^{14}$.

Wiedzę historyczną o średniowieczu zaczęto budować także na podstawie inskrypcji i napisów umieszczonych na monetach i pieczęciach zebranych w prywatnych kolekcjach. Na terenie Terra Ferma, czyli włoskich posiadłości Wenecji, istniało wiele kolekcji w typie gabinetów uczonych, $\mathrm{z}$ których właściciele czerpali informacje o charakterze dokumentalnym do swych prac. Lorenzo Pignoria (1571-1631), kolekcjoner i antykwariusz w Pawii, oprócz obrazów i rycin, posiadał portrety sławnych ludzi, posągi, starożytne medale z Grecji, Rzymu i innych regionów, medale nowożytne, pieczęcie, starożytne narzędzia, jednostki miary i wagi, klucze, fibule, pierścienie, lampy, amulety oraz wytwory natury: muszle, kamienie, kryształy i przedmioty egzotyczne z Chin i Indii.

${ }^{12}$ Tamże, s. 284-286; zob. też: S. Mikucki (red.), Nauki pomocnicze historii w Uniwersytecie Jagiellońskim, w: Studia z dziejów Wydziału Filozoficzno-Historycznego Uniwersytetu Jagiellońskiego, Kraków 1967, s. 154-160.

${ }^{13}$ Szczegółowe, erudycyjne studium tego zagadnienia prowadzi Krzysztof Pomian w publikacji pt. Zbieracze i osobliwości. Paryż-Wenecja XVI-XVIII wiek, wydawanej w j. francuskim w 1987 roku, w j. polskim - kilkakrotnie; tu powołuję się na najnowsze z 2012 roku, w thumaczeniu Andrzeja Pieńkosa.

${ }^{14}$ Tamże, s. 107-124, 298. 
Należy uciec się do rzeczy, które ją [historię] uzasadniają, a których ludzka złośliwość i niewiedza nie zdołały naruszyć. Należy uwierzyć zabytkom przeszłości, której medale są znakami najpewniejszymi i najbardziej dostępnymi apelował Charles Patin, lekarz i numizmatyk, autor obszernego opracowania na temat monet i medali pod wymownym tytułem Introduction à l'histoire par la connaissance des médailles $(1665)^{15}$. W drugiej połowie XVII wieku pieczęcie zaczęły nabierać znaczenia w kolekcjach włoskich. W spuściźnie po Giovannim Lazara Starszym (1621-1690) znajduje się poszyt poświęcony pieczęciom padewskim i weneckim zebranym w jego kolekcji, z których wybrane reprodukowano w rycinach. Giovanni Lazara zamierzał opublikować wszystkie według spisów pt. Sigilli spettanti a Padova da far intagliare oraz pt. Sigilli da far intagliare. Jednak nie zdołał tego uczynić. Na początku XVIII wieku średniowieczne monety i pieczęcie weneckie znajdowały się już w kilku kolekcjach w Padwie i Wenecji, a w 1733 roku Apostolo Zeno, wenecki pisarz i homme des lettres, kupił 500 średniowiecznych pieczęci, które odsprzedał po upływie czterech lat. Do lat 40. XVIII wieku kolekcje w Terra Ferma liczyły po niemal 6000 monet i medali oraz do 20000 obiektów kultury materialnej. Kolejnym ważnym kolekcjonerem, który w 1744 roku wydał publikację o historii monet w Wenecji okresu średniowiecza, jest ks. Giovanni Brunacci. Zgromadził on kolekcję, w skład której wchodziły m.in. pieczęcie biskupów weneckich i którą zrecenzowano przychylnie w 1765 roku:

Wszystkie te rzeczy umieścił on razem, aby ukazać dzieje świeckie i kościelne tego miasta i tej diecezji, czego bardzo oczekują uczeni. Nie mówię nawet o innych zabytkach i niezliczonych pergaminach oryginalnych albo wyciągniętych $\mathrm{z}$ archiwów, które przechowuje u siebie, jako że to mnie nie dotyczy. Jednakże amatorzy starego malarstwa będą mieli przyjemność obejrzenia kilku utworów starego malarstwa, które zdają się pochodzić z XIII w. albo jego okolic; są one już dziwaczne i tej niezręcznej maniery, która, jak to niektórzy utrzymują, panowała w owym czasie. Ma on ponadto mały obraz naszego Andrei Mantegni ${ }^{16}$.

We Francji na uwagę zasługuje kolekcja sfragistyczna François Roger de Gaignères'a licząca na przełomie XVII/XVIII wieku ok. 30000 oryginalnych odcisków pieczętnych ${ }^{17}$.

W Polsce historia erudycyjna znalazła zainteresowanie dopiero w XVIII wie$\mathrm{ku}$, stanowiąc zaplecze dla syntetyzującej myśli historiozoficznej Oświecenia ${ }^{18}$. Złudzeń co do znajomości sfragistyki w XVII-wiecznej Polsce nie pozostawia zdanie zapisane przez Tadeusza Czackiego w publikacji poświęconej polskiemu i litewskiemu prawodawstwu, w której zostały wydrukowane tablice z ilustracjami polskich monet, ale nie pieczęci:

15 Tamże, s. 102-104.

${ }^{16}$ Cyt. za tamże, s. 296 z publikacji G.B. Rossetti, Descrizione delle pitture, sculture ed architetture di Padova con alcune osservazioni intorno ad esse ed altre curiose notize, Padova 1765.

${ }^{17}$ M. Haisig, Bolesław Podczaszyński. Sfragistyk i archeolog, Wrocław 1952, s. 18.

${ }^{18}$ Grabski, Dzieje historiografii, s. 320. 
Kiedy u nas herby weszły, niewiem; Paprockiego, Okolskiego i Niesieckiego herbarze, nie mają dostatecznych dowodów, a podobno na naukę o pieczątkach nie rzucili oka ${ }^{19}$.

Tadeusz Czacki sporadycznie powoływał się na traktat Jeana Mabillona ${ }^{20}$, ale sam zagadnienia związane $\mathrm{z}$ pieczęciami omówił jedynie $\mathrm{w}$ przypisie swej publika$\mathrm{cji}^{21}$. Historycy polscy końca XVIII i pierwszej połowy XIX wieku postrzegali pieczęcie przede wszystkim jako pomoc w studiach dyplomatycznych czy heraldycznych, ewentualnie jako przyczynek do ikonografii polskich pieczęci. Tablice z wybranymi ich wizerunkami drukowali przy okazji publikowania dokumentów źródłowych ${ }^{22}$.

Tylko Joachim Lelewel, publikując w 1822 roku systematykę nauk pomocniczych historii, omówił zakres badań dyplomatyki i sfragistyki. Jednak w rozdziale poświęconym sfragistyce skoncentrował się przede wszystkim na zagadnieniach związanych $\mathrm{z}$ dyplomami, sposobem ich zapisywania i znakowania, a nie na opisie i charakterystyce pieczęci ${ }^{23}$. Wysiłki, jakie podejmowali kolejni badacze, wiązały się z publikowaniem wizerunków polskich pieczęci, rozpoznaniem ge-

${ }^{19}$ T. Czacki, O Litewskich i Polskich prawach o ich duchu, źródłach, związku, i o rzeczach zawartych w pierwszym Statucie dla Litwy 1529 roku wydanym, [1 wydanie: Warszawa 1800]; korzystałam z wydania K. Turowskiego, Kraków 1861, s. 80, przyp. 1; J. Szymański, Sto lat przemian metodologicznych nauk pomocniczych historii $w$ Polsce, w: Tradycje i perspektywy nauk pomocniczych historii $w$ Polsce. Materiaty z sympozjum w Uniwersytecie Jagiellońskim dnia 21-22 października 1993 roku, red. M. Rokosz, Kraków 1995, s. 36. Stefan Krzysztof Kuczyński działania w zakresie sfragistyki polskich historyków początku XIX w. określa jako daleko skromniejsze od tych w Europie zachodniej. S.K. Kuczyński, Kazimierz Stronczyński jako sfragistyk $i$ heraldyk, w: Kazimierz Stronczyński. Numizmatyk, sfragistyk i inwentaryzator zabytków. Materiały sesji naukowej, Piotrków Trybunalski 1983, s. 23.

${ }^{20}$ „Pieczęci były własnością familiów. Kiedy kto nie miał, pożyczał od drugiego, jak Mabillon de re diplomatica na karcie 148 okazuje". Czacki, O Litewskich i Polskich prawach, s. 84.

${ }^{21}$ Tamże, s. 80, przyp. 1.

${ }^{22} \mathrm{~K}$. Stronczyński, Wzory pism dawnych w przerysach wystawione i objaśnione drukowanem ich wyczytaniem, Cz. 1. obejmująca pismo dyplomatów od roku 1228 do 1536, Warszawa 1839; Kodeks dyplomatyczny Wielkiej Polski, Poznań 1840 wyd. E. Raczyński; Zbiór praw litewskich od roku 1389. do roku 1529 tudzież rozprawy sejmowe o tychże prawach od roku 1544. do roku 1563., red. A.T. Działyński, Poznań 1841; pierwsze wydanie Lites ac Res gestae inter Polonos Ordinemque Cruciferorum, wyd. T. Działyński, t. 1 i 2, Posnaniae 1855, t. 3 Posnaniae 1856; por. też: M. Gumowski, M. Haisig, S. Mikucki, Sfragistyka, Warszawa 1960, s. 43-45. O początkach zainteresowania sfragistyką w Polsce pisali także: Mikucki, Nauki pomocnicze historii, s. 153-183; Z. Perzanowski, Z dziejów Zakładu Nauk Pomocniczych Historii i Archiwistyki w Uniwersytecie Jagiellońskim, w: Tradycje i perspektywy nauk pomocniczych historii w Polsce. Materiaty z sympozjum w Uniwersytecie Jagiellońskim dnia 21-22 października 1993 roku, red. M. Rokosz, Kraków 1995, s. 21-27; A. Gieysztor, Nauki dające poznawać źródła historyczne w Uniwersytecie Warszawskim, w: Tradycje i perspektywy nauk pomocniczych, s. 29-33; Szymański, Sto lat przemian, s. 35-47; ostatnio: S.K. Kuczyński, Początki polskich badań sfragistycznych na tle europejskim, w: Pieczęcie $w$ dawnej Rzeczypospolitej. Stan i perspektywy badań, red. Z. Piech, J. Pakulski, J. Wroniszewski, Warszawa 2006, s. 11-29.

${ }^{23}$ J. Lelewel, Nauki dające poznawać źródła historyczne, Wilno 1822; korzystałam z wydania poznańskiego z 1863 roku, s. 38-45. 
nezy pieczęci w Polsce, klasyfikacją na polskie i litewskie, królewskie i książęce. Pobieżnie traktowano omówienie zmian przedstawień napieczętnych w czasie, materiałów i technik wykonania oraz umieszczania przy dokumentach ${ }^{24}$.

Utrwalił ten punkt widzenia Friedrich August Vossberg, który w 1854 roku ogłosił drukiem najobszerniejszy wówczas zbiór wizerunków pieczęci, dodatkowo zaopatrzony przez autora w informacje o ich wystawcach. Zwracał uwagę na rolę pomocniczą pieczęci nie tylko w dyplomatyce, genealogii i numizmatyce, ale także $\mathrm{w}$ historii sztuki ${ }^{25}$. Było to nowością $\mathrm{w}$ piśmiennictwie historycznym traktującym o pieczęciach związanych $\mathrm{z}$ historią państwa polskiego, ale nie w literaturze poświęconej historii sztuk pięknych, ponieważ pieczęcie budziły zainteresowanie nie tylko w środowisku historyków. Już w latach 30. XIX wieku zostały wprzęgnięte w kształtowanie programu polskiej historii i kultury, a szczególnie historyczno-narodowej ikonografii. Wincenty Pol, snując refleksje o podjęciu działań prowadzących do pobudzenia malarstwa w Polsce - i w konsekwencji powstania narodowej szkoły malarstwa - postulował utworzenie muzeum narodowego ze zbiorami m.in. pieczęci. Pisał:

(...) potrzeba nam naprzód zbieraczy starożytności polskich. A zatem potrzeba nam wizerunków ruin zamków, chat dworów i kościołów, rysunków medali starożytnej Polski, pieczęci koronnych ruskich i litewskich, klejnotów ziem, miast i rodzin szlacheckich; potrzeba nam posiadać, jak najzupełniejsze zbiory portretów historycznych obrazów, rycin i cacek, rysunki strojów i rynsztunków, wizerunki grobów i mogil, nagrobków i widoków ziemi, starych charakterów i ozdób; wizerunki świętych i głośnych kraju obrazów i całego widoku drewnianej i murowanej Polski. (...) Wszakże zbiory podobne stałyby się u nas abecadłem historycznego malarstwa; o nie dopiero mogłaby się oprzeć sztuka, one byłyby także stanowiskiem, z którego ogół wychodził i mógł sądzić

${ }^{24}$ Czacki, O Litewskich i Polskich prawach, s. 80-84, przyp. 1; F.A. Vossberg, Siegel des Mittelalters von Polen, Lithauen, Schlesien, Pommern und Preussen. Ein Beitrag zuf Förderung diplomatischer, genealogischer, numismatischer und Kunstgeschichtlicher Studien über ursprunglich Slavische Theile der Preussischen Monarchie, Berlin 1854; T. Żebrawski, O pieczęciach dawnej Polski i Litwy, Kraków 1865. Założenia metodologiczne nauk pomocniczych historii, czyli dyscypliny pozwalającej na organizowanie krytycznych zabiegów wokół źródła, co gwarantować miało uzyskanie poprawnych informacji w nim zawartych, znane już Jeane Mabillonowi, wśród polskich historyków pierwszej połowy XIX wieku bliskie były Joachimowi Lelewelowi. Opierając się na doświadczeniach francuskich oraz zmianach zachodzących w europejskiej filozofii, sposobach poznania oraz historiografii i krytyce źródeł, Lelewel historię pojmował jako naukę wyjaśniającą proces historyczny i zmierzającą do syntez, naukom zaś, które zamierzał integrować z historią, nadał ostatecznie status autonomicznych. Jednak większość polskich historyków zainteresowana była niemieckimi wzorcami traktowania źródeł. Śladem grupy uczonych, skupionych wokół wydawców Monumenta Germaniae Historia (1819), zamierzali publikować źródła jako zabezpieczenie pomników kultury narodowej. Sytuację nauk pomocniczych historii zmienił Theodor von Sickel wraz z kierowanym przez siebie Instytut für Oesterreichische Geschichtsforschung. Współpracując z prawnikiem, Juliuszem Ficnerem, skoncentrował uwagę badawczą na dyplomatyce i wypracował kryteria krytyki źródeł dyplomatycznych. Szymański, Sto lat przemian, s. 38-40. O zmianach metodycznych i metodologicznych rzutujących na postrzeganie historii oraz rolę krytyki dokumentu w pierwszej połowie XIX wieku zob. też Mikucki, Nauki pomocnicze historii, s. 160, 182-183.

${ }^{25}$ Vossberg, Siegel des Mittelalters. 
o wartości dzieł malarskich. Podobne zbiory stałyby się szkołą starożytności dla narodu, a żywe pojęcie onych utworzyłoby dla sztuki symbolikę własną ${ }^{26}$.

Franciszek Maksymilian Sobieszczański, historyk-samouk o zamiłowaniach artystycznych, w rozdziale pt. O pieczęciach $w$ wiekach średnich zamieszczonym w książce poświęconej zabytkom sztuk pięknych w dawnej Polsce, zwracał uwagę na konieczność opracowania pieczęci jako dzieł sztuki. Objaśniał pieczęcie polskie, biorąc pod uwagę kilka kryteriów: wystawcy, opisu przedstawienia, analizy znaczenia i genezy wybranych przykładów. Wskazał w ten sposób rolę pieczęci w badaniach nie tylko nad prawem, dyplomatyką, chronologią, genealogią, heraldyką i etnografią, ale także nad dziejami sztuk pięknych ${ }^{27}$. Podnosząc walory artystyczne i ikonograficzne rzeźbionych pieczęci, uzasadniał ich wysoką ocenę w kolekcjach:

Zbiór pieczęci, chociażby w odciskach z oryginalnych, byłby równie interesującym jak starożytne kamee; a ogłoszenie w rysunku i opis, nie tylko dla dziejów krajowych, ale i dla historyi sztuk pięknych pożądanym ${ }^{28}$.

Odnotował przy tym kilka znanych mu zbiorów wizerunków i odcisków pieczętnych: rysunki i grafiki Kajetana Wincentego Kielisińskiego, odlewy z brązu u Kazimierza Stronczyńskiego, oryginalne odciski przy dokumentach w Głównym Archiwum Krajowym w Warszawie oraz w zbiorach prywatnych Gwalberta Pawlikowskiego w Medyce, Leona Rzyszczewskiego i Józefa Rusieckiego w Warszawie ${ }^{29}$.

${ }^{26}$ W. Pol, O malarstwie i żywiołach jego w kraju naszym, ,Tygodnik Literacki literaturze, sztukom pięknym i krytyce poświęcony”, (1839), nr 24, s. 186-187. Poglądy W. Pola były znane i uznane. Gdy w 1849 roku przybył do Krakowa, Towarzystwo Naukowe Krakowskie mianowało go członkiem Oddziału Nauk Moralnych, a 19 stycznia 1850 roku Wydział Filozoficzny Uniwersytetu Jagiellońskiego nadał mu stopień doktora. Postulowany przez W. Pola program muzeum narodowego był z uwagą analizowany przez Towarzystwo, ponieważ to właśnie jemu powierzyło opracowanie memoriału w sprawie powołania Muzeum Starożytności w Krakowie. J. Hanik, J. Rosnowska, Pol Wincenty w: Polski Stownik Biograficzny (dalej: PSB), t. 27, Wrocław-Warszawa-Kraków 1983, s. 259-260. Członkiem Towarzystwa był już Teofil Żebrawski. Teofil Żebrawski, http://tnk.krakow. pl/czlonkowie/zebrawski-teofil/ (dostęp: 04.07.2019).

${ }^{27}$ F.M. Sobieszczański, Wiadomości historyczne o sztukach pięknych $w$ dawnej Polsce, t. 1, Warszawa 1847, s. 182-210. Pisał: „Pod względem sztuki żaden może oddział rzeźby tak dokładnego o jej postępie nie daje wyobrażenia co pieczęcie; symboliczna i charakterystyczna ich rozmaitość, ulepszenie ich ozdób, delikatność wyrobu w tych pracach, często w zadziwienie wprawie. Stąd też znakomitą one mają od monet wyższość, już to iż są obszerniejsze, już iż więcej artystyczności w nich spostrzegać się daje. Dostarczają one nadto wiele szczegółów archeologią i etnografią mocno obchodzących; bowiem na przedstawionych figurach widzimy rodzaj ubioru, broni, osoby jakich używano, postacie książąt, rycerzy stojących zwykle w bramach swych zamków lub miast, których wizerunek i rodzaj budownictwa spostrzegamy. Pieczęcie królewskie majestatyczne, wielkiego rozmiaru, w bogate ozdoby rysunku obfitują. Pieczęcie biskupie, przedstawiają Biskupów albo obok swoich kościołów, albo na tronie siedzących; zaś pieczęcie kapitulne wyobrażają dokładne wizerunki katedr itd. Słowem: zabytki tego rodzaju są nader zajmującemi i powabnemi i życzyłby należało aby pod tym względem więcej się niemi zajmowano". (s. 182-183).

${ }^{28}$ Tamże, s. 183. Stefan Krzysztof Kuczyński pisze wprost o „odkryciu wartości źródłowej zabytków pieczętnych dla historii sztuki” w tamtym czasie przez Kazimierza Stronczyńskiego. Kuczyński, Kazimierz Stronczyński, s. 24.

${ }^{29}$ Sobieszczański, Wiadomości historyczne, s. 3-4, 185-186, przyp. 2. 
Wątek użyteczności pieczęci dla sztuki oraz badań na temat dawnych mebli, strojów, regaliów poruszył również kolejny miłośnik starożytności, kolekcjoner i polihistor, Teofil Żebrawski w opracowaniu królewskich i książęcych pieczęci Polski i Litwy opublikowanym w 1865 roku $^{30}$. Pominął książkę F.M.Sobieszczańskiego $\mathrm{w}$ tekście i spisie bibliograficznym. Własne doświadczenia nabywał, opierając się na publikacjach historyków oraz klasyfikacji pieczęci podjętej w 1858 roku, po otwarciu Wystawy Starożytności w Krakowie, gdy opracowywał część poświęconą sfragistyce nigdy nieopublikowanego katalogu. Wówczas największy problem w badaniach polskiej sfragistyki dostrzegał w braku usystematyzowanej wiedzy o kompletnej ikonografii pieczęci, co uniemożliwiało ich naukową klasyfikację stosowaną od dawna na Zachodzie ${ }^{31}$.

Publikacje F.M. Sobieszczańskiego, w pewnym stopniu także T. Żebrawskiego, miały charakter przełomowy wśród Polaków o tyle, o ile obaj autorzy przestali traktować pieczęcie wyłącznie w kategoriach wskazanych w dyplomatyce, czyli funkcjonalnych, oraz z perspektywy potrzeb historii erudycyjnej, czyli źródła informacji o kulturze materialnej, a zaczęli postrzegać je jako część kultury wizualnej i artystycznej, jako płaskorzeźby poddawane tej samej ocenie, co inne dzieła sztuki. Obaj korzystali z francuskiej, XVII-wiecznej historii erudycyjnej oraz refleksji z zakresu kolekcjonerstwa, w której podstawą oceny dzieła sztuki była umiejętność „,wiernego badania ducha i ręki artysty” i analizowania techniki jego pracy $^{32}$. Podobną opinię prezentował Bolesław Podczaszyński; możemy przy-

${ }^{30}$ Publikacja Teofila Żebrawskiego O pieczęciach dawnej Polski i Litwy, Kraków 1865.

${ }^{31}$ „Nie mamy dotąd zupełnego spisu pieczęci naszych, aby podobnie jak w spisie monet i medali odwołać do tegoż przy wyszczególnieniu pieczęci, któreśmy na wystawie widzieli: liczba zaś przysłanych na wystawę, tak jest małą, iż byłoby bez naukowej korzyści klasyfikować je na monarchiczne, duchowne, itp. Układ chronologiczny byłby najwłaściwszy, gdyby znany był rok każdego dyplomu, od którego pieczęć oderwaną została. Wypada nam przeto poprzestać na rozłożeniu pieczęci na dwa oddziały, to jest pieczęci właściwych, czyli wycisków na wosku, i tłoków czyli narzędzi do ich wytłaczania, a w każdym oddziale takowe w abecadłowym porządku krótko opisać". Biblioteka Polskiej Akademii Nauk i Polskiej Akademii Umiejętności w Krakowie (dalej: BPAU/PAN), sygn. 1488, t. 6, Wstęp do Katalogu wystawy starożytności narodowych, urządzonej w Krakowie w r. 1858, składka Pieczęcie na wosku wytloczone (wszystkie ze zbioru Mieczysława Pawlikowskiego), k. 1.

${ }^{32}$ To pogląd na rolę kolekcjonera i ocenę zbiorów propagowany od połowy XVIII w. przez hrabiego Caylusa, który zamiast gromadzenia cennych dzieł oraz wykorzystywania ich, przede wszystkim medali, do uzyskania wiadomości historycznych zalecał ,wiernie badać ducha i rękę Artysty, dać się prowadzić jego wzrokowi, przyglądać się jego technice, słowem, widzieć w zabytkach świadectwo smaku, który panował w pewnym stuleciu i w pewnym kraju”. Twierdził, że w porównaniu z medalami, które dotąd zajmowały najwięcej uwagi kolekcjonerów, ślady pracy artystów są znacznie bardziej czytelne w gemmach, a zwłaszcza rzeźbach. Pomian, Zbieracze i osobliwości, s. 161 na podstawie wstępu Caylusa do publikacji Reueil d'antiquités égyptiennes, étrusques, grecques et romaines, t. 1, Paris 1752. Caylus zwracał uwagę kolekcjonerów na technikę rzeźbiarską i jej wytwory, jako szczególnie cenne dla analiz „smaku”, czyli - stosując współczesną terminologię analiz stylistycznych i zaakcentowania aspektów artystycznych i plastycznych w kolekcji, nie zaś wyłącznie historycznych. 
puszczać, że - przynajmniej w środowisku warszawskim - była istotna, mimo że zawarta $\mathrm{w}$ nigdy nieopublikowanych notatkach, ale zapewne popularyzowana w trakcie spotkań i specjalistycznych konsultacji ${ }^{33}$.

Przygotowując się do napisania wspomnianych opracowań T. Żebrawski miał wyjątkową okazję współpracy z kolekcjonerem Gwalbertem Pawlikowskim i z malarzem Janem Matejką, czyli osobami, które w pieczęciach nie dostrzegały wyłącznie źródła do badań nad heraldyką, ale zwracały na nie bystrą uwagę jako na nośniki różnorodnych informacji o przeszłości i na dzieła plastyczne świadczące o możliwościach artystycznych dawnych twórców.

Gwalbert Pawlikowski był kolekcjonerem typowym dla pierwszej połowy XIX wieku. Koncepcję zbiorów opierał na doświadczeniach historii erudycyjnej Zachodu oraz potrzebach i zaleceniach historyków i historyków sztuki. W ślad za tym rozbudował odziedziczoną kolekcję o liczne egzemplarze numizmatów i pieczęci. Bliskie były mu idee Izabeli Czartoryskiej - gromadzenia pamiątek po dawnej Rzeczypospolitej - i rozmach kontrybucyjny Francuza, barona Dominique Vivant-Denona, a także praktyka archiwariuszy francuskich z lat 18001830, którzy przy porządkowaniu dokumentów odcinali przywieszone do nich pieczęcie ${ }^{34}$.

Zbierajmy co możemy, wydobywajmy z grobu Polski niegdyś tak świetne świadki naszej poczciwej sławy, spajajmy starej ojczyzny rozproszone szczątki i kiedy już nadziei mieć nie możemy, żyjmy przynajmniej we wspomnieniach -

pisał do księżnej Izabeli Czartoryskiej generał Franciszek Morawski ${ }^{35}$. Jego apel bliższy był szczytnym celom Aleksandra Lenoire'a, który w czasie rewolucji francuskiej ratował zabytki przed zniszczeniem niż postawie reprezentowanej przez barona D. Vivant-Denon'a, który ocalał podczas rewolucji dzięki znajomości z malarzem Jacquesem-Louisem Davidem, a potem, w czasie zwycięskich walk generała Napoleona Bonaparte, dokonywał kontrybucji dzieł sztuki z krajów „wyzwalanych” przez wojska Republiki, by zrealizować cel przekształcenia Luwru w największe muzeum świata ${ }^{36}$. Nie inaczej działali T. Czacki na Wawelu,

${ }^{33}$ Uważał, że pieczęć (woskowy odcisk lub odlew) dawała ,pod względem rzeźbiarskiej sztuki większe pole rozwinięcia obrazów od numizmatu”. Haisig, Bolesław Podczaszyński, s. 21; stamtąd cytat.

${ }^{34}$ Praktykę tę uzasadniali argumentem o deformowaniu przez pieczęcie tek, w których przechowywano dokumenty. Tamże, s. 18.

${ }^{35}$ Z. Żygulski, Dzieje zbiorów puławskich (Światynia Sybilli i Dom Gotycki), „Rozprawy i Sprawozdania Muzeum Narodowego w Krakowie", 2 (1962) s. 95.

${ }^{36}$ Warunek kontrybucji dzieł sztuki i kultury wpisywany był do traktatów kapitulacyjnych, np. papiestwo oddać musiało w ten sposób „100 obrazów, popiersi, naczyń lub posągów wedle wyboru komisarzy, którzy będą wysłani do Rzymu; wśród tych przedmiotów znajdzie się w szczególności brązowy biust Juniusa Brutusa i marmurowy biust Marka Brutusa, umieszczone obecnie na Kapitolu; ponadto 500 rękopisów wedle wyboru tychże komisarzy”. Polacy, najwierniejsi sojusznicy Bonapartego, stracili wtedy m.in. 4 weduty Canaletta, Hołd pruski Marcelego Bacciarellego z Sali Rycerskiej w Zamku Królewskim w Warszawie, Gdańsk opuścił Sąd Ostateczny Hansa Memlinga. Jedynie Galeria Uffizi wyszła obronną ręką tracąc tylko Wenus Medycejską, ponieważ powołała 
dysponując królewskim pełnomocnictwem jako członek Komisji Skarbu Koronnego, a czasem sama księżna Izabela Czartoryska gromadząca pamiątki po dawnej Rzeczypospolitej w imię hasła umieszczonego na Świątyni Sybilli w Puławach: „Przeszłość przyszłości” ${ }^{77}$. Większość kupowała lub otrzymywała w darze, jak np. ,trzy słupki marmurowe z grobu Kazimierza Wielkiego” w katedrze krakowskiej, które ofiarować jej miała kapituła katedralna poruszona wyrażonym przez księżną gorącym pragnieniem ich posiadania ${ }^{38}$.

W tej sytuacji zrozumiały staje się zapał kolekcjonerski innych zamożnych Polaków, który nie ominął archiwum cystersów w Mogile. Zasoby archiwalne wyposażyły w takim stopniu prywatne kolekcje, także zebraną przez G. Pawlikowskiego w Medyce ${ }^{39}$, iż ks. dr Eugeniusz Janota, badający w latach 60. XIX wieku dokumenty w mogilskim archiwum, pisał:

Gdy się obejrzym na ubiegłych lat sto i spomnim, ile to materyjałów historycznych zniszczało w tym czasie przez nieszczęsne wypadki, więcej jeszcze przez niedbałość, a najwięcej przez złość ludzką, ile ich rozszarpano i Bóg wie, gdzie rozproszono, mimowolnie gorące powstaje życzenie spiesznego wydobywania na jaw tego, co ocalało ${ }^{40}$.

Sami Krakowianie-starożytnicy w połowie XIX wieku krytycznie ocenili działalność T. Czackiego, pośrednio - także księżnej I. Czartoryskiej ${ }^{41}$, a z Pawlikow-

się na fakt, że jej kolekcja od dawna należy nie do książąt, ale do narodu. Z. Żygulski, Muzea na świecie. Wstęp do muzealnictwa, Warszawa 1982 s. 54-55.

${ }^{37}$ Sama Czartoryska tak osądzała cel gromadzenia pamiątek w Świątyni Sybilli w Puławach: „W tych latach, w których tyle klęsk nas przycisnęło, kiedy nas z rzędu narodów wymazano, mówiłam sobie ze łzami: Ojczyzno! Nie mogłam ciebie obronić, niechaj cię przynajmniej uwiecznię! Ta chęć, to uczucie przywiązało mnie do życia. Wystawiłam naówczas świątynię pamięci, zebrałam tam pamiątki tej Polski niegdyś tak świetnej, a wtenczas tak nieszczęśliwej. Tam żyłam w przeszłości, a czasem w moich dumaniach tchnęłam nadzieją szczęśliwej przyszłości”. Cyt. za: L. Dębicki, Puławy, t. 2, Lwów 1887, s. 11-12.

${ }^{38}$ Żygulski, Dzieje zbiorów puławskich, s. 48.

${ }^{39}$ Ze względu na znaczenie poznania losów części rozproszonego zbioru pieczęci klasztoru w Mogile informacje na ten temat zostały umieszczone w Aneksie do artykułu.

${ }^{40}$ Diplomata monasterii clarae tumbae prope Cracoviam. Zbiór dyplomatów klasztoru mogilskiego przy Krakowie, wydany staraniem i nakładem C. K. Towarzystwa Naukowego Krakowskiego, w drukarni C.K. Uniwersytetu Jagiellońskiego pod zarządem Ferd. Schmiedehausena, Kraków 1865, przedm. E. Janota, oprac. Franciszek Piekosiński, s. VIII. W tej sprawie zob. też M. Starzyński, Herby średniowiecznych opatów mogilskich, Kraków 2005, s. 17-20.

${ }^{41}$ „Był czas, że prześwietna kapituła krakowska, złożona z niedołęgów obojętnych na dawne pomniki i pamiątki, pozwoliła groby królów naszych znieważyć zabieraniem z nich kosztownych i szanownych pod różnym względem pamiątek. Świętokradztwa tego dopuścił się uczony śp. Tadeusz Czacki”. E. Danowska, Tadeusz Czacki 1765-1813. Na pograniczu epok i ziem, Kraków 2006, s. 157-158; cyt. za: Danowska, Tadeusz Czacki, s. 157 z notatek w Tekach Grabowskiego, Archiwum Narodowe w Krakowie, Teki Grabowskiego, sygn. E 17; także Żygulski, Dzieje zbiorów puławskich, s. 39-40. O nieufności członków Towarzystwa Naukowego Krakowskiego do dyletanckich badań archeologicznych prowadzonych bez sporządzenia podstawowej dokumentacji i amatorskiego kolekcjonerstwa prywatnych „lubowników starożytności” oraz o chęci nadania naukowego kierunku takim wysiłkom podejmowanym przez polską szlachtę i inteligencję zob. B. Schnaydrowa, 
skimi, żyjącymi w czasach im współczesnych, współpracowali, wypożyczając od nich przedmioty na wystawy i do badań naukowych. Jednak, mimo tej współpracy, T. Żebrawski piętnował publicznie złe praktyki kolekcjonerów pieczęci:

znaczną także liczbę pieczęci nas dotyczących, przy dyplomatach i bez tychże posiadają. (...) Nierozważny zapał robienia zbiorów z samych pieczęci, dał powód do nieocenionych i niczem niepowetowanych szkód, jakich się ich zbieracze dopuścili, odrzynając je od dyplomatów i pozbawiając je przez to wzajemnej autentyczności i znaczenia: znam wiele takich pieczęci po zbiorach prywatnych, na których nie zapisano nawet, od jakiego dyplomu lub z jakiego roku pochodzą ${ }^{42}$.

Niektórzy zamiast odcinania pieczęci lub wynoszenia dokumentów z archiwów gromadzili ich odlewy ${ }^{43}$ lub rysunki, jak wspomniany już K.W. Kielisiński przebywający w Krakowie między rokiem 1834 a 1836. Współpracował z tutejszymi starożytnikami, utrwalając ołówkiem wizerunki zabytków miasta i okolic: kościoły, baszty, mury obronne, nagrobki, herby, pieczęcie i typy mieszkańców. Ze szczególną pieczołowitością dokumentował pieczęcie. W 1842 roku miał zgromadzonych 470 ich wizerunków, z których ponad 30 przedstawiało pieczęcie przywieszone do dokumentów w archiwum klasztoru cysterskiego w Mogile ${ }^{44}$. Po śmierci rysownika w 1849 roku 43 wizerunki pieczęci rozmieszczonych przez K. Kielisińskiego na 12 tablicach wydano w Albumie Kielisińskiego. Autor Wstępu chwalił talent rysowniczy K. Kielisińskiego: „niezrównaną prawie doskonałość osiągnął w pracowitem, wiernem i artystycznem oddawaniu monet i pieczęci" od czasów najdawniejszych po egzemplarze z okresu panowania Wazów. Powoływał się także na ocenę G. Pawlikowskiego, który zwracał uwagę nie na ikonografię, ale artystyczne zalety stworzonych wizerunków:

W pracach tych, powiada Pawlikowski, jego rysunek najdoskonalszy, do mikroskopicznych nawet szczegółów zupełnie zachowany; charakter rzeźby całkiem pojęty: znajdziesz w rysunku ducha i sposób ręki mincarza [wyróżnie-

Z dziejów krakowskiej Wystawy Starożytności, „Rocznik Biblioteki PAN w Krakowie”, 23 (1977) s. 134-135.

${ }^{42}$ Najpierw wymienił dwie - jego zdaniem - najważniejsze kolekcje: po Gwalbercie Pawlikowskim w Medyce i Tytusa Działyńskiego w Kórniku, a potem napiętnował złe kolekcjonerskie praktyki, więc nietrudno było zorientować się, których kolekcjonerów miał na myśli. Żebrawski, O pieczęciach dawnej, s. 17.

${ }^{43}$ Do Muzeum Starożytności przy Towarzystwie Naukowym Krakowskim ponad 40 odlewów przekazał T. Żebrawski. Z kolei Bolesław Podczaszyński z Warszawy podarował Towarzystwu 104 odlewy. Zob. BPAU/PAN, sygn. 3697, Księga darów 1859-1871, nry 218, 404, 420, 1377.

${ }^{44}$ Autor wstępu do Albumu Kielisińskiego informował o cennych przedmiotach znajdujących się w pokoju, w kórnickim zamku zamieszkiwanym przez K. Kielisińskiego: ,porozwieszane i porozstawiane akwarelle, ryciny, rysunki, zalegające na stołach i krzesłach teki szkiców i wzorów, stare pergaminy i księgi, zbutwiałe pieczęcie". Niestety, nie napisał, ile tych pieczęci było i skąd pochodziły oraz czy były własnością K. Kielisińskiego, czy były wypożyczone od T. Działyńskiego. Zob. też. J. Orańska, Kajetan Wincenty Kielisiński w świetle dokumentów i prac w zbiorach kórnickich, Kórnik 1947, s. 12, 18. 
nie - $\mathrm{BC}$ ], odgadniesz kruszec z którego metal był bity czy lany, w pieczęciach dostrzeżesz i miękkość wosku, i przez czas nadaną krągłość wystającej rzeźbie, i tę nawet pleśń starości i poniewierki podziwiać będziesz ${ }^{45}$

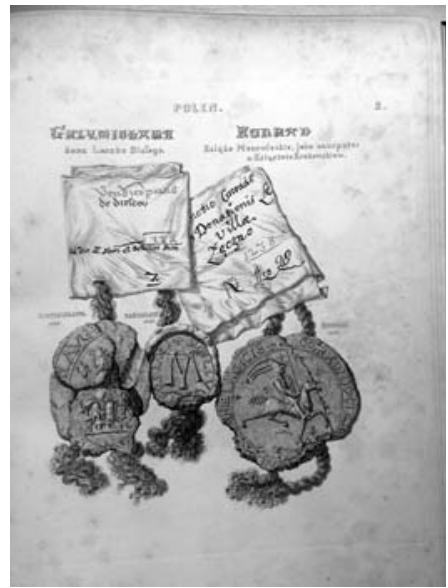

I1.2. Kajetan Wincenty Kielisiński, Pieczęcie Grzymisławy, Pakosława, wojewody krakowskiego i Konrada Mazowieckiego przywieszone do dokumentów w archiwum klasztoru cystersów w Mogile, F. A. Vossberg, Siegel des Mittelalters von Polen, Lithauen, Schlesien, Pommern und Preussen, Berlin 1854, Taf. 2.

W ślad za postulatami W. Pola do środowiska podejmującego wysiłek ochrony pamiątek narodowych dołączyło Towarzystwo Naukowe Krakowskie (TNK). Jego prezes, dr Józef Majer, pełniący jednocześnie funkcję rektora Uniwersytetu Jagiellońskiego, opublikował w 1850 roku apel w sprawie założenia muzeum pamiątek krajowych przy Bibliotece Uniwersytetu Jagiellońskiego:

Towarzystwo Naukowe Krakowskie wydelegowało z grona swego, jak wiadomo, komitet archeologiczny, mający na celu gromadzenie pamiątek krajowych, i tego wszystkiego, co tylko zdolnem jest wtajemniczyć nas w przeszłość naszę. Towarzystwo czując zupełny brak archeologii ojczystej, widząc jak najdroższe pomniki i zabytki starożytne przepadają z dniem każdym, zamierzyło przez obywatelską gorliwość mieszkańców kraju utworzyć muzeum przy bibliotece uniwersytetu Jagiellońskiego.

Dozór i opracowanie naukowe przyszłych zbiorów powierzono komitetowi, w skład którego weszli członkowie TNK: Józef Muczkowski, profesor i bibliotekarz, W. Pol, profesor Uniwersytetu Jagiellońskiego, Karol Kremer, dyrektor

${ }^{45}$ Wstęp do Albumu Kielisińskiego, Poznań 1853., b.n.s. Autor wspomina, że zbiór wizerunków pieczęci polskich liczy ok. 500 sztuk i jest w posiadaniu Tytusa hr. Działyńskiego z Kórnika. Tablicami rytowanymi przez K. Kielisińskiego na podstawie jego własnych rysunków pieczęci posługiwano się kilkakrotnie ilustrując m.in.: Statut Litewski Działyńskiego (1841), wydawnictwo Vossberga Siegel des Mittelalters, Tytusa Działyńskiego Lites ac reges inter Polonos ordinemque Cruciferorum, Orańska, Kajetan Wincenty Kielisiński, s. 19-20. Określenie „ducha i sposobu ręki mincerza", użyte przez autora Wstępu do Albumu Kielisińskiego, przypomina wprost sformułowanie użyte wiek wcześniej przez hrabiego Caylusa. Por. przyp. 32. 
budownictwa, i T. Żebrawski, inspektor komunikacji lądowej i wodnej ${ }^{46}$. W tym samym roku TNK wydało odezwę ze wskazówkami, jak należy prowadzić poszukiwania owych pamiątek, wśród których wymieniono pieczęcie sklasyfikowane w dziale „rzeźba" ${ }^{47}$.

W 1858 roku staraniem Oddziału Archeologii i Sztuk Pięknych TNK otwarto wspominaną już Wystawę Starożytności ${ }^{48}$ i T. Żebrawski rozpoczął działalność badawczo-popularyzatorską w zakresie sfragistyki.

Kilka lat wcześniej u J. Muczkowskiego pojawił się J. Matejko, student krakowskiej Szkoły Sztuk Pięknych. Istotne jest to, że J. Muczkowski, będąc uczniem Jerzego Samuela Bandtkiego, zainteresowanego zagadnieniami dyplomatyki, sam - gdy został dyrektorem Biblioteki Jagiellońskiej - rozwijał zainteresowania naukami pomocniczymi historii. W roku akademickim 1851/1852 dał wykład pod tytułem zaczerpniętym wprost z pracy J. Lelewela: „Nauki dające poznać źródła historyczne", a w latach 1850-1857 prowadził wykłady z numizmatyki, dyplomatyki i paleografii ${ }^{49}$. Jan Matejko był bratem Franciszka Matejki, bibliotekarza i historyka slawisty, od 1868 roku pierwszego na Uniwersytecie Jagiellońskim docenta prywatnego nauk pomocniczych historii (bibliografii, dyplomatyki, heraldyki i numizmatyki), który w latach akademickich 1870/1871 oraz 1871/1872 wykładał „nauki dające poznać źródła historyczne”, już w samym tytule odwołując się do książki J. Lelewela. Co więcej, Józef Łepkowski, przyjaciel J. Matejki od lat 60. XIX wieku, w roku akademickim 1870/1871 dał na Uniwersytecie Jagiellońskim wykład poświęcony zabytkom starożytności w Muzeum Archeologicznym, zwłaszcza pieczęciom polskim, a w roku 1871/1872 wykład pt. Sfragistyka ${ }^{50}$.

Jeszcze podczas studiów w krakowskiej Szkole Sztuk Pięknych, w latach 1851-1858, J. Matejko zamierzał zostać malarzem historycznym i poszukiwał materiałów ilustracyjnych, które pozwoliłyby mu przedstawić historię przy po-

${ }^{46}$ Doniesienia Literackie, „Biblioteka Warszawska”, 3 (1850) s. 574-575; cyt. s. 574.

${ }^{47}$ Dział IV, Zabytki z czasów chrześciańskich, zawierający uwagi na temat rzeźb, podzielony został na trzy poddziały: 1) Posągi i rzeźby, 2) pieczęcie, 3) rzeźby stanowiące nieoddzielną część budynku, Odezwa Towarzystwa Naukowego z Uniwersytetem Jagiellońskim połaczonego w celu archeologicznych poszukiwań wraz ze skazówka mogaca posłużć za przewodnika w poszukiwaniach tego rodzaju, Kraków 1850, s. 28-31. W 1858 r. Towarzystwo zrealizowało postulat pokazania polskich starożytności oraz ponowiło wydanie Skazówki pod nowym tytułem: Skazówka poszukiwań $i$ badań starożytności wydana przez Oddziat Archeologii i Sztuk Pięknych w C.K. Towarzystwie Naukowym Krakowskiem, Kraków 1858.

${ }^{48}$ Schnaydrowa, Z dziejów krakowskiej Wystawy Starożytności, s. 131-132, 135-137, 146-147.

${ }^{49}$ Mikucki, Nauki pomocnicze, s. 156, 158; Szymański, Sto lat przemian, s. 37.

${ }^{50}$ W. Bieńkowski, Matejko Franciszek Ksawery Edward, PSB, t. 20, Wrocław-Warszawa-Kraków 1975, s. 183-184. Tytuł wykładu jest tożsamy z tytułem publikacji J. Lelewela Nauki dajace poznawać źrzódła historyczne, zob. przyp. 19, i jednocześnie identyczny z tytułem wykładu J. Muczkowskiego wygłoszonym w roku akademickim 1851/1852, zob. tekst artykułu oraz przyp. 23. W tym kontekście warto przypomnieć, że F. Matejko był uczniem Michała Wiszniewskiego, wykładającego historię powszechną na Uniwersytecie Jagiellońskim, ale przywiązującego również dużą wagę do nauk pomocniczych. Mikucki, Nauki pomocnicze, s. 157-160 oraz Bieńkowski, Matejko Franciszek; J. Dybiec, Michat Wiszniewski jako profesor historii powszechnej w Uniwersytecie Jagiellońskim, „Kwartalnik Historii Nauki i Techniki”, 9 (1964) nr 2, s. 225. 
mocy rekwizytów z epoki - strojów, broni, architektury. Nie chciał bowiem zadawalać się naśladowaniem kostiumów używanych w teatrze podczas sztuk historycznych. Nawiązał kontakty ze środowiskiem krakowskich starożytników i kolekcjonerów: Ambrożym Grabowskim, hrabią Piotrem Moszyńskim, księciem Jerzym Henrykiem Lubomirskim, a ponadto penetrował zabytki Krakowa i oko$\operatorname{lic}^{51} \mathrm{w}$ poszukiwaniu materiału ikonograficznego do wydania pierwszego albumu kostiumologicznego, który ostatecznie opublikował w 1860 roku pt. Ubiory w Polsce. Gromadząc materiał ilustracyjny, przeglądał książki, m.in. publikację F.A. Vossberga, skąd skopiował na kalkach reprodukowane tam ilustracje pieczęci, w tym wszystkie dotyczące Polski i Litwy ${ }^{52}$. Poznał Album Kielisińskiego z 1853 roku, skąd także kopiował ilustracje ${ }^{53}$. Środowisko krakowskie w młodym malarzu widziało następcę K. Kielisińskiego, wybitnie zainteresowanego przeszłością Polski postrzeganą nie inaczej jak poprzez zachowane zabytki i pamiątki.

Kazanie Skargi (1864), nagrodzone w 1865 roku na Salonie w Paryżu medalem I klasy, najwyższą nagrodą, którą mógł uzyskać debiutant, przyniosło J. Matejce rozgłos wśród Polaków jako wybitnie utalentowanego malarza historycznego. Jesienią tego samego roku został mianowany członkiem TNK, a od redakcji warszawskiego „Tygodnika Ilustrowanego” otrzymał propozycję, by przysyłać rysunki, które będą następnie publikowane w formie graficznej jako ilustracje do krótkich tekstów historycznych. Czym szczególnie zainteresowani byli redaktorzy ,Tygodnika”? W pierwszym numerze, który ukazał się w 1859 roku, ogłosili program czasopisma:

barwa [...] będzie czysto krajowa. Zbierając skrzętnie i wydzierając zapomnieniu wszystko, co tylko ma związek z przeszłością, wszystko, w czym tętni życie narodowe, pismo to stanie się kiedyś zbiorem godniejszych uwag i wspomnień historycznych, opisów o rysunków, bogatym składem zostawionej nam po przodkach puścizny, w której rozpatrując się, poznamy samych siebie ${ }^{54}$.

Deklaracja współgrała z zainteresowaniami J. Matejki. Pierwszym rysunkiem umieszczonym w „Tygodniku” był widok krypty pod kaplicą Oświęcimiów przy kościele franciszkanów w Krośnie opublikowany 4 września 1865 roku ${ }^{55}$. Następ-

${ }^{51}$ B. Ciciora, Matejko a średniowiecze. Zainteresowania - inspiracje - realizacje, Kraków 2009, mps, rozprawa doktorska napisana pod kierunkiem prof. dra hab. Wojciecha Bałusa w Instytucie Historii Sztuki Uniwersytetu Jagiellońskiego, Archiwum Uniwersytetu Jagiellońskiego, sygn. 2009/095, s. 48 oraz noty katalogowe rysunków w przygotowanym do druku Katalogu rysunków Jana Matejki w zbiorach Muzeum Narodowego w Krakowie. Cz. 1. Studia z natury (dalej: Ciciora, Katalog rysunków); przedstawienia na rysunkach przechowywanych w Domu Jana Matejki, oddziale Muzeum Narodowego w Krakowie (dalej: DJM), np. o numerach inwentarzowych IX/471, IX/472, IX/476, wskazują kolekcje, z których Matejko korzystał, rysując obiekty, gdy był jeszcze studentem krakowskiej Szkoły Sztuk Pięknych.

${ }^{52}$ Rysunki w DJM, nry inw.: IX/1701 - IX/1714, IX/1731, IX/1774 - IX/1777, IX/1794 IX/1796, IX/1866, IX/2082 - IX/2083, IX/2183.

${ }^{53} \mathrm{~Np}$. wizerunki Litwinów, rysunki w DJM, nry inw.: IX/1872 - IX/1873.

${ }^{54}$ Prospekt „Tygodnika Ilustrowanego” podpisany przez Józefa Ungra 20 sierpnia 1859 roku, bns.

${ }^{55}$ „Tygodnik Ilustrowany”, (1865) nr 312, s. 116 z tekstem Władysława Ludwika Anczyca pt. Grób Stanisława i Anny Oświęcimiów w Krośnie wydrukowanym w dziale „Pamiątki historyczne, pomniki, starożytności, kostiumy i zabytki przeszłości”. 
nie ukazały się m.in. portrety postaci historycznych, których wizerunki przedstawił artysta na podstawie studiów ich malowanych konterfektów oraz portretów utrwalonych na medalach, nagrobkach i epitafiach ${ }^{56}$.

Należy zauważyć, że moment debiutu artysty na łamach „Tygodnika Ilustrowanego" był nieprzypadkowy. Grafika według jego rysunku została opublikowana we wrześniu, natomiast kilka miesięcy wcześniej, 13 maja, ukazał się na łamach periodyku tekst F. Matejki o renesansowym miniaturzyście chorwackim, Giorgio Giulio Clovio, którego żywot opisał Giorgio Vasari. Clovio, kiedy dotarł do Włoch, wykonał dla kardynała Marino Grimaniego, miłośnika sztuki, rysunki medali, pieczęci „, innych utworów przeznaczonych do rycia, a to z niezmierną, prawie do wiary niepodobną starannością", co zanotować miał G. Vasari ${ }^{57}$. Zainteresowania F. Matejki wykraczały, jak widać, szeroko poza ramy typowe dla badaczy historii i koncentrowały się na zagadnieniach bliskich naukom pomocniczym historii, historii sztuki oraz studiom slawistycznym. To cenna wskazówka świadcząca o tym, iż w razie potrzeby Jan mógł liczyć na merytoryczną i metodyczną pomoc starszego brata w zakresie kwerend źródłowych.

Na podstawie zachowanych rysunków możemy z pewnością stwierdzić, że impulsem dla J. Matejki do objęcia poszukiwaniami ikonograficznymi także dokumentów historycznych stały się badania wsi Mogiła i tamtejszego opactwa cystersów przeprowadzone w połowie lat 60 . XIX wieku przez TNK, którego członkiem stał się J. Matejko jesienią 1865 roku. Efektem prac historyków były dwie publikacje wydane w 1865 roku: Diplomata monasterii Clarae Tumbae prope Cracoviam. Zbiór dyplomatów klasztoru mogilskiego przy Krakowie, z przedmową ks. Eugeniusza Janoty, a opracowane przez późniejszego wybitnego polskiego sfragistyka, Franciszka Piekosińskiego, oraz Monografia opactwa cystersów we wsi Mogile opracowana i pamięci ubiegtych w r. 1864 pięciuset lat istnienia Akademii Krakowskiej poświęcona przez Towarzystwo Naukowe Krakowskie, wydana w 1867 roku.

We wstępie do Zbioru dyplomatów klasztoru mogilskiego, napisanym 15 września 1865 roku, ks. E. Janota informował:

Prócz znacznej ilości dokumentów oryginalnych posiada klasztor mogilski jeszcze inne rękopisy, z których przy ułożeniu katalogu dyplomatycznego tego miejsca wypadało korzystać, gdyż się okazało, że niejeden dokument zaginął.

${ }^{56} \mathrm{Na}$ przykład drzeworyty przedstawiające wizerunki królowej Bony („Kłosy”, (1867) nr 80, s. 17), biskupa Jana Dziaduskiego (,Wieniec”, (1872) nr 4, s. 28), Bohdana Chmielnickiego (,Kłosy”, (1877) nr 604, s. 57), Jana Załogi („,Tygodnik Ilustrowany”, (1867) nr 430, s. 293). Jan Załoga, wykładowca Uniwersytetu Jagiellońskiego w XV wieku, był postacią mało znaną w XIX stuleciu. Jan Matejko posłał jego wizerunek, sprawiając kłopot wydawcy z opracowaniem biogramu. Redakcja napisała wprost, że reprodukuje rysunek, ponieważ taki przysłał im J. Matejko: „Jan Matejko odkrył w kościele dominikanów innego Ałogę, Jana, akademika z XVI wieku, którego wizerunek z pomnika z właściwym mu talentem zdjęty, do pisma naszego przesłał”. „Tygodnik Ilustrowany”, (1867) nr 430, s. 293.

${ }^{57}$ F. Matejko, Jerzy Juliusz Klowio, miniaturzysta chorwacki (Ur. 1498, + 1578), „Tygodnik Ilustrowany", (1865) nr 294, s. 173-174; cytat: s. 174. 
(...) W miejscach do odczytania trudniejszych lub w jakibądź sposób wątpliwych zasięgano zdania Dra A. Z. Helcla i Dra T. Żebrawskiego ${ }^{58}$.

A zatem T. Żebrawski, poproszony o konsultacje przez ks. E. Janotę, poznał dość dokładnie zasób archiwum mogilskiego, a wraz z nim - bezcenne pieczęcie średniowieczne przywieszone do dokumentów. W opracowaniu pieczęci polskich pt. O pieczęciach dawnej Polski $i$ Litwy, opublikowanym w 1865 roku, czyli tym samym, w którym Towarzystwo opublikowało Zbiór dyplomatów klasztoru mogilskiego, pisał:

Znajomość dawnych pieczęci stanowi jednę z pomocy historyi (...) a lubo wszelkie dawnej sztuki zabytki są obfitem źródłem do poznania dawnych ubiorów, uzbrojeń, sprzętów, kształtów budowli i ozdób architektonicznych, oraz smaku i stopnia, na jakim stała sama sztuka w odpowiednich latach, to pieczęcie mają tę przed innemi sztuki utworami korzystną dla badacza stronę, iż wskazują epoki nie wiekami, lecz prawie dziesiątkami lat naznaczone ${ }^{59}$.

Raczej trudno podejrzewać, by J. Matejko nie był do tej pory świadom, iż pieczęcie należą do tych rzadkich zabytków, które można datować z dokładnością do dziesięciolecia ${ }^{60}$, a ponadto ukazują wizerunki władców i ludzi Kościoła epoki średniowiecza, czyli czasu gdy - w przeciwieństwie do architektury - historyczne źródła ikonograficzne niemal nie zachowały się. Jan Matejko był też świadom wagi ostrzeżenia, którego udzielił w swej publikacji krakowski polihistor:

Zwracamy uwagę na tę okoliczność, iż do proporcyj ciała, a tym bardziej do rysów twarzy, żadnej na pieczęciach wagi przywiązywać nie należy: dosyć jest przytoczyć wysoką i wysmukłą postać Władysława Łokietka na jednej z książęcych jego pieczęci (z 1310 r.), lub wąsatą twarz Władysława Warneńczyka siedzącego na tronie, na pieczęci z 1438 roku, kiedy król ten liczył dopiero piętnaście lat życia ${ }^{61}$.

Jan Matejko nie miał jednak innej możliwości: jako malarz albo mógł korzystać z wizerunków przedstawionych w źródłach historycznych, mając świadomość niemożności zweryfikowania przedstawienia $\mathrm{z}$ wizerunkiem $\mathrm{w}$ innym historycznym źródle, albo mógł fantazjować, jak dotychczas czynili inni artyści.

Rok wydania kodeksu mogilskiego oraz monografii T. Żebrawskiego (1865) poprzedza rozpoczęcie przez J. Matejkę intensywnego gromadzenia studiów pieczęci, nawet takich, których wizerunki miał już skopiowane z publikacji

${ }^{58}$ Diplomata monasterii clarae tumbae, s. III, V.

${ }^{59}$ Żebrawski, O pieczęciach dawnej, s. 3.

${ }^{60} \mathrm{Już}$ w czasie gromadzenia materiału ikonograficznego do Ubiorów w Polsce, np. podczas stypendium w Monachium, J. Matejko odrysował postać Marii Brabanckiej, królowej Niemiec i cesarzowej, córki Henryka IV Brabanckiego, żony Ottona IV, z ilustracji pieczęci cesarzowej reprodukowanej w publikacji A. v Eye. J. Falke, Kunst und Leben der Vorzeit von Beginn des Mittelalters bis zu Anfang des 19. Jahrhundets, Nürnberg 1858, Bd. 1, b.n.s; rysunek w DJM, nr inw.: IX/1860. W tym czasie skopiował też ilustracje pieczęci z publikacji F.A. Vossberga, Siegel des Mittelalters. Por. przyp. 52.

${ }^{61}$ Żebrawski, O pieczęciach dawnej, s. 10-11. 
F.A. Vossberga. Pieczęcie rysował J. Matejko jesienią 1866 roku w zbiorach TNK i Biblioteki Jagiellońskiej ${ }^{62}$. W tym i w 1867 roku wykonał najprawdopodobniej większość studiów pieczęci.

Co skłoniło artystę do podjęcia tego ogromnego wysiłku? Z pewnością odegrał tu rolę zbieg kilku okoliczności. Po pierwsze, nasilenie badań sfragistycznych W środowisku krakowskim, z którym J. Matejko utrzymywał bliskie kontakty (T. Żebrawski, F. Matejko), uświadomiło malarzowi istnienie obfitej ikonografii w obrębie tego historycznego źródła, niewykorzystanej dotąd przez twórców w celach nie tyle poznawczych i badawczych w służbie historii, ile w celach artystycznych. Po drugie, przyjęcie słynnego malarza historycznego, nagrodzonego w Paryżu, w poczet członków Oddziału Archeologicznego i Sztuk Pięknych Towarzystwa Naukowego Krakowskiego, co otwierało przed nim niedostępne archiwa. Po trzecie, opracowane przez Józefa Szujskiego i Hipolita Seredyńskiego dzieje opactwa w Mogile ${ }^{63}$ i wydawane w tym samym czasie przez J. Szujskiego Dzieje Polski (1862-1866) umożliwiły poznanie postaci nie pierwszoplanowych, ale istotnych dla polskiej historii. Dzięki wizerunkom zachowanym na pieczęciach J. Matejko mógł wykreować średniowieczny wygląd tych postaci. Po czwarte, mógł przy pomocy obrazów olejnych lub ilustracji graficznych, publikowanych w tygodnikach ilustrowanych, spopularyzować czasy polskiego średniowiecza, którymi dotąd artyści albo rzadko interesowali się właśnie z braku opracowań i dostępu do źródeł ikonograficznych, albo przedstawiali je w sposób ahistoryczny, nieprzekonujący widza drugiej połowy XIX wieku ${ }^{64}$

Wybór pieczęci, którego dokonał, zdaje się wskazywać, że wiele widniejących na nich postaci narysował pod wpływem tekstu o przeszłości klasztoru mogilskie-

${ }^{62}$ Niestety, tylko tyle informacji zawarł siostrzeniec żony J. Matejki, Antoni Serafiński, w liście przesłanym rodzinie 13 grudnia 1866 roku. S. Serafińska, Jan Matejko. Wspomnienia rodzinne, wyd. 2, Kraków 1958, s. 197. Innych informacji źródłowych nie mamy. Możemy tylko wnioskować na podstawie badań rysunków. Większość studiów pieczęci powstała w 1866 i być może w 1867 roku. Jednak sporadycznie mogły powstawać później, jak studium pieczęci Jana Luksemburskiego (DJM, nr inw. IX/1563), które J. Matejko narysował między rokiem 1875 a 1877, przygotowując się do malowania obrazu Bitwa pod Grunwaldem. Zob. Ciciora, Katalog rysunków, część Studia pieczęci.

${ }^{63}$ J. Szujski, Wiadomość historyczna o Mogile, w: Monografia opactwa Cystersów we wsi Mogile, Kraków 1867, s. 5-24 oraz H. Seredyński, Uposażenie klasztoru cystersów w Mogile, Monografia opactwa Cystersów, s. 73-86.

${ }^{64} \mathrm{Na}$ przykład ilustracje Antoniego Oleszczyńskiego przedstawiające wydarzenia z polskiej historii zostały poddane krytyce przez J. Lelewela. J. Polanowska, Oleszczyński Antoni, w: Stownik Artystów Polskich, t. 6, Warszawa 1998, s. 246. Z krytyką spotkały się także inne wydawnictwa: „Za najlepsze źródło do czasów przed Kazimierzem W.[ielkim] trudno jest uznać Myliusa. Niepodobna się było ograniczać tą jedną tylko księgą, gardząc drzeworytami kronik, które rysowane były początkowo ze starych obrazów”. J.I. Kraszewski, Listy do Redakcji Gazety Warszawskiej, „Gazeta Warszawska”, (1853) Nr 205, s. 4; zob. też J.I. Kraszewski, Dodatek do „Gazety Warszawskiej”, (1853) Nr 208, s. 6-7. Wydawnictwo Myliusa, o którym pisał J.I. Kraszewski, to: Arnoldus Mylius, Principum ac Regum Polonorum imagines ad vivum expressa, Coloniae 1594, dobrze znane Amrożemu Grabowskiemu, który wspominał o nim w swoich notatkach, jako o źródle do ikonografii polskich królów. Archiwum Narodowe w Krakowie, sygn. E 72, Teki Grabowskiego. 
go, pióra J. Szujskiego, opublikowanego w monografii Mogiły. Jan Matejko narysował niemal wszystkie wymienione tam postaci z XII-XIII wieku. Józef Szujski, o czym nie należy zapominać, był starszym kolegą, a później przyjacielem J. Matejki. Wraz z malarzem i wieloma innymi, młodszymi osobami: historykami (Tadeusz Wojciechowski, Ludwik Kubala), literatami, artystami, aktorami, muzykami, należał do grupy tzw. Przedburzowców, kręgu znajomych spotykających się w latach 1857-1865, oficjalnie - celem omówienia swych utworów i prac, a nieoficjalnie - by prowadzić dyskusję o historii i przyszłości Polski ${ }^{65}$. Zebrania dla J. Matejki stały się kolejnym impulsem do poszerzania wiedzy historycznej, a przede wszystkim historiozoficznego spojrzenia na przeszłość. Zafascynowany - jak wielu członków - wiedzą J. Szujskiego, w pierwszej połowie lat 60. XIX wieku „wszystko, co wyszło z druku J. Szujskiego, skwapliwie czytał”66.

Cóż fascynującego napisał J. Szujski? W tekście Wiadomość historyczna o Mogile wydanym w Monografii opactwa cystersów we wsi Mogile w 1867 roku, tak zarysował tło polityczne dla fundacji Mogiły w czasach Leszka Białego:

duchowieństwo rzuciło podwalinę ogromnej swojej w Polsce przewagi, popierając młodszą linię Krzywoustego przeciw starszej wielkopolskiej. Były to czasy, gdy książęca władza niknęła prawie obok biskupiej, która kolejno zrzuciła $\mathrm{z}$ tronu Władysława Laskonogiego, odsunęła od następstwa Mieczysław Starego, wygnała syna jego Władysława Laskonogiego z Krakowa, a obecnie wyjednała u Stolicy Apostolskiej prawo dziedzictwa najstarszemu synowi Kazimierza, zwanego Sprawiedliwy. Samodzielność książęca skonała z Mieczysławem Starym, ostatnim, nieszczęśliwym spadkobiercą monarchicznej Chrobrego myśli. Chwila jeszcze a i Wielkopolska owa gałąź pochyli dumny swój kark przed pastorałem.

W Małopolsce dokonała swym wpływem tej ważnej odmiany rodzina Gryfitów, sprowadzona przez Krzywoustego z Syrbii nadłabskiej, mianowicie zaś Gedeon biskup i Stefan wojewoda, krakowscy. Ich drogą poszedł Pełka (Fulko) herbu Lis, biskup krakowski, główna Leszkowego tronu podpora; poszła rodzina Odrowążów, której wielkość i znaczenie historyczne rozpoczyna się od biskupa krakowskiego Iwona" ${ }^{67}$.

Józef Szujski na tle fundacji cysterskich w Europie i Polsce oraz na podstawie dokumentów przechowywanych w archiwum mogilskich cystersów ukazał splot działań fundatorów świeckich i duchownych prowadzący do powstania kolejnych klasztorów oraz nakreślił syntetycznie dalsze dzieje opactwa w Mogile. Przypomniał m.in. rolę takich postaci, jak biskupi krakowscy, Pełka, Iwon, jego krewni z rodu Odrowążów, Wisław i Dobiesław, a także - Konrad Mazowiecki. Ponadto opisał przywileje zwolnień z danin lub powinności, nadawane włościom klasz-

${ }^{65}$ J. Maciejewski, Przedburzowcy. Z problematyki przełomu między romantyzmem a pozytwizmem, Kraków 1971, s. 8, 29-41; W. Mossakowska, Fotografia przyjaciót Artura Grottgera $i$ Walerego Rzewuskiego z 1865 roku, w: Fotografia. Od dagerotypu do Galerii Hybrydy. Materiaty z sesji naukowej zorganizowanej przez Oddział Warszawski Stowarzyszenia Historyków Sztuki, red. D. Jackiewicz, Z. Jurkowlaniec, Warszawa 2008, s. 32-43.

${ }^{66}$ I. Jabłoński-Pawłowicz, Wspomnienia o Janie Matejce, Lwów 1912, s. 59.

${ }^{67}$ Szujski, Wiadomość historyczna o Mogile, s. 11. 
tornym przez Henryka Brodatego i Bolesława Wstydliwego, a także czas niemieckiego osadnictwa i prawodawstwa za panowania Wacława II Czeskiego oraz Władysława Łokietka ${ }^{68}$.

Wizerunki wymienionych postaci narysował J. Matejko na podstawie ich pieczęci zachowanych przy dokumentach klasztornych lub w innych archiwach i zbiorach Krakowa i Galicji. Powstały w ten sposób dwa studia postaci na pieczęci Iwona Odrowąża ${ }^{69}$, studium postaci na pieczęci Sąda Dobiesławowicza, kasztelana wojnickiego $\mathrm{z}$ rodu Odrowążów ${ }^{70}$, studium postaci na pieczęci księcia Henryka Brodatego ${ }^{71}$, studium postaci na pieczęci biskupa krakowskiego Prędoty ${ }^{72}$, studium postaci na pieczęci Bolesława I, księcia mazowieckiego i sandomierskiego, ponieważ J. Matejko sądził, iż jest to pieczęć Konrada Mazowieckiego ${ }^{73}$.

$\mathrm{Na}$ rysunku przedstawiającym studium pieczęci księcia mazowieckiego J. Matejko zanotował ,z pieczęci jednego z $6^{\text {ciu }}$ Mnichów $\mid$ Mogilskich którzy wyklęli księcia | Oświęcimskiego". Notatka odnosiła się do widniejącego na rysunku drugiego studium, czyli studium pieczęci prezbitera Jakuba, przywieszonej do dokumentu wystawionego przez Jana Grotowica w dniu 28 czerwca 1345 roku $^{74}$. Według notatki, biskup krakowski polecił proboszczom w Zatorze, Oświęcimiu i we wsi Hartmanna ogłosić, że rzuca klątwę na Jana, księcia oświęcimskiego, jeżeli ten nie zastosuje się w oznaczonym terminie do wyroku biskupa oraz własnego przyrzeczenia i nie zwróci klasztorowi w Mogile niesłusznie zajętej wsi Woźnik. Treść dokumentu zgadza się z treścią notatki J. Matejki, co świadczy o tym, iż malarz był zainteresowany nie tylko historią Polski zawartą w kronikach i opracowaniach współczesnych historyków, ale także szczegółowymi informacjami $\mathrm{w}$ dokumentach źródłowych klasztoru, które podczas rysowania pieczęci mógł mu przekazać archiwista.

Arcybiskup Pełka, biskupi Nanker, Wisław z Kościelca, Jan Grotowic, Florian z Mokrska należeli do głównych bohaterów historii Polski XIII-XIV wieku opisanej przez J. Szujskiego w pierwszym tomie Dziejów Polski. Opierając się na studiach postaci na ich pieczęciach w mogilskim klasztorze, J. Matejko wykreował

${ }^{68}$ Tamże, s. 11-14.

${ }^{69}$ Pieczęć przywieszona do dokumentu z 1222 r.; Ciciora, Katalog rysunków; Kaczmarczyk, Kowalski, Katalog Archiwum Opactwa, nr kat. 2. Szczegółowe studium postaci Iwona na pieczęci zachowane jest w Muzeum Narodowym w Warszawie, nr inw.: 75 436, szkic ołówkiem - w DJM, nr inw.: IX/1544.

${ }^{70}$ Pieczęć przywieszona do dokumentu z 1236 r.; Ciciora, Katalog rysunków, DJM, nr inw. IX/1539; Kaczmarczyk, Kowalski, Katalog Archiwum Opactwa, nr kat. 14.

${ }^{71}$ Pieczęć przywieszona do dokumentu z 1238 r.; Ciciora, Katalog rysunków, DJM, nr inw. IX/1535; Kaczmarczyk, Kowalski, Katalog Archiwum Opactwa, nr kat. 15.

${ }^{72}$ Pieczęć przywieszona do dokumentu z 1243 lub 1244 r.; Ciciora, Katalog rysunków, DJM, nr inw. IX/1524; Kaczmarczyk, Kowalski, Katalog Archiwum Opactwa, nr kat. 18, 20. Na tej samej karcie J. Matejko wykonał studium postaci na innej pieczęci biskupa Prędoty, przywieszonej do dokumentu z 1263 roku w Archiwum Krakowskiej Kapituły Katedralnej.

${ }^{73}$ Pieczęć przywieszona do dokumentu z 1231 r.; Ciciora, Katalog rysunków, DJM, nr inw. IX/1522; Kaczmarczyk, Kowalski, Katalog Archiwum Opactwa, nr kat. 12.

${ }^{74}$ Ciciora, Katalog rysunków, DJM, nr inw. IX/1522; Kaczmarczyk, Kowalski, Katalog Archiwum Opactwa, nr kat. 71. 
bądź pojedyncze postacie, bądź też kilkufiguralne scenki służące wizualizacji opracowań historycznych w postaci grafik ilustracyjnych w „Tygodniku Ilustrowanym” oraz w „Kłosach”75. Postać Konrada, opata klasztoru cystersów w Koprzywnicy, zwróciła uwagę J. Matejki zapewne nie ze względu na jej znaczenie historyczne lub informacje źródłowe w odnośnym dokumencie, ale ze względu na strój i pastorał opacki, a także drobny, ażurowy, gotycki ornament i detale architektoniczne czytelne na dobrze zachowanym odcisku pieczętnym. Wizerunek Konrada z pastorałem i księgą inspirował artystę do wykreowania postaci Wincentego Kadłubka na rysunku wykonanym pod drzeworyt zatytułowany „Rysunki Jana Matejki. Wincenty Kadłubek biskup krakowski, w poczcie benedyktynów. Odtworzył ze starych pieczęci Jan Matejko" rytowany przez Jana Schübelera i opublikowany w 1872 roku, w ,Tygodniku Ilustrowanym” wraz z towarzyszącym mu komentarzem historycznym o postaci Wincentego Kadłubka pt. „Wincenty Kadłubek w poczcie benedyktynów. (Rysunek Jana Matejki)"’76.

${ }^{75}$ Pieczęć arcybiskupa gnieźnieńskiego, Pełki (Fulka) przywieszona jest do dokumentu z 1243 roku przechowywanego w klasztorze w Mogile. Ciciora, Katalog rysunków, DJM, nr inw. IX/1535; Kaczmarczyk, Kowalski, Katalog Archiwum Opactwa, nr kat. 18.

Pieczęć biskupa Nankera przywieszona jest do dokumentu z 1325 r. przechowywanego w klasztorze w Mogile, Ciciora, Katalog rysunków, DJM, nr inw. IX/1521; Kaczmarczyk, Kowalski, Kata$\log$ Archiwum Opactwa, nr kat. 58.

Pieczęć Wisława z Kościelca przywieszona jest do dokumentu z 1236 roku przechowywanego w klasztorze w Mogile. Jej studium posłużyło artyście do wykonania w 1875 roku (data na drzeworycie) rysunku pod drzeworyt pt. Rysunki Jana Matejki. Wisław z Kościelca, biskup krakowski rytowany przez J. Krajewskiego i opublikowany w „Kłosach” (1879, Nr 726, s. 345) z tekstem „W” pt. Wistaw herbu Zabawa, s. 350. Na rysunku J. Matejko zapisał kilka uwag: dwie porządkowe (informacja o właścicielu herbu Rawicz przedstawionego na tym samym rysunku, co Wisław: „h Rawicz | należący | do następ.[cy] | Jana Grota” oraz napis w otoku pieczęci: „, S. Wislai | ORA .... C | Episcopi | rp. 1236.”), a także informację historyczną o postaci biskupa: „Wisław z Kościelca | Kanonik h. Zabawa | po Iwonie spór wiódł | z Andrzejem - później bis. płocki. - scholastykiem | synem Marka Wojew. Krak. | h. Gryf. pokrył kościół na zamk[u] po pożarze | za Iwona i wieże wystawił | oraz w Proszowicach koś.”). Ciciora, Katalog rysunków; DJM, nr inw. IX/1534; Kaczmarczyk, Kowalski, Katalog Archiwum Opactwa, nr kat. 14. Pieczęć Jana Grotowica jest z kolei przywieszona do dokumentu z 1334 roku przechowywanego w klasztorze w Mogile. Jej studium posłużyło artyście do wykonania w 1870 roku rysunku pod drzeworyt pt. Jan Grot (Z pieczęci), rytowany przez Jana Styfiego i opublikowany na Tab. 12 Albumu Jana Matejki wydawanego przez Samuela Lewentala w latach 1873-1876. Ciciora, Katalog rysunków; DJM, nr inw. IX/1528; Kaczmarczyk, Kowalski, Katalog Archiwum Opactwa, nr kat. 65.

Pieczęć Floriana z Mokrska przywieszona jest do dokumentu z 1377 roku przechowywanego w klasztorze w Mogile, Il. 7. Jej studium posłużyło artyście do wykonania rysunku pod drzeworyt pt. „Rysunki Jana Matejki. Floryan Mokrski, biskup krakowski w wieku XIV. (Odtworzył Matejko, według starej pieczęci” rytowany przez Jana Schübelera i opublikowany w „Tygodniku Ilustrowanym” (1871, Nr 168, s. 129) z tekstem „F.M.S.” [Franciszka Maksymiliana Sobieszczańskiego - przyp. B.C.] pt. Floryan Mokrski, biskup krakowski, tamże, s. 130 (Il. 8), Ciciora, Katalog rysunków, DJM, nr inw. IX/1537; Kaczmarczyk, Kowalski, Katalog Archiwum Opactwa, nr kat. 116.

${ }^{76}$ Pieczęć Konrada, opata klasztoru cystersów w Koprzywnicy, przywieszona jest do dokumentu z 1390 roku przechowywanego w klasztorze w Mogile. Drzeworyt został opublikowany w „Tygodniku Ilustrowanym” (1872, Nr 221, s. 152) z tekstem „L.J.” pt. Wincenty Kadlubek w po- 
Obok przedstawienia opata umieścił J. Matejko studium pieczęci Leszka Białego z napisem w otoku: „[+ SIGIL'] DVCIS LEZTCONIS”, wskazującym na właściciela pieczęci. Mimo iż napis informował o księciu jako właścicielu pieczęci, J. Matejko sądził, że dokument opieczętowała Grzymisława, a nie jej mąż Leszek Biały, zamordowany pół roku wcześniej. Na karcie, obok rysunku, zapisał: ,,po śmierci (Leszka Białego) | przycisnęła Grzymisława na dyplomie | mogilskim”. Pieczęć ta nie ukazywała wizerunku księcia, ale heraldycznego orła. Była wyjątkowa także pod innymi względami, co szeroko komentował T. Żebrawski w swej publikacji z 1865 roku, zapewne znanej J. Matejce: należała do najstarszych pieczęci polskich władców zachowanych w zbiorach Polaków i znanych $\mathrm{w}$ oryginale, a nie tylko z reprodukcji jak pieczęć Ryksy, ponadto należała do grupy najstarszych pieczęci polskich, na których umieszczono herb, jednocześnie dokumentowała formowanie się kształtu herbu Piastów i polskiego godła ${ }^{77}$. Uwagę J. Matejki przyciągnęła jeszcze jedna pieczęć, wojewody Marka, przywieszona do tego samego dyplomu, co pieczęć Leszka Białego. Artysta na karcie szkicownika, obok jej studium, naszkicował trzy różne znaki graficzne, poszukując wśród znanych mu herbów analogii do zatartego kształtu widniejącego na pieczęci; obok zapisał przypuszczenia na ten temat: „Radwan? | czy Odrową[ż?]”.

Zainteresowanie XIII-wiecznymi pieczęciami wzbudził $\mathrm{w}$ artyście także T. Żebrawski, który starał się uchwycić początki pojawienia się herbów na pieczęciach, wskazując te z XII wieku, reprodukowane przez F.A. Vossberga, oraz egzemplarze z XIII wieku ${ }^{78}$. Jednak pieczęcie urzędników, nawet najwyższych, nie znalazły zainteresowania w oczach J. Matejki, chyba że posiadały ikonografię, która mogła stać się użyteczna dla malarza historycznego, czyli mogła być wykorzystana do kreacji postaci historycznych na obrazach lub na grafikach ilustracyjnych. Z tego względu wśród rysunków J. Matejki znalazło się także studium pieczęci komesa Pakosława Starszego, wojewody krakowskiego, przywieszonej do dokumentu z 1238 roku w mogilskim archiwum $^{79}$.

Podobnie zagadnienia heraldyczne nie leżały w obszarze zainteresowań J. Matejki. W swoich studiach artysta niemal całkowicie pomijał pieczęcie pokojowe, sygnetowe, herbowe i contrasigilla z przedstawieniem wyłącznie herbów,

czcie benedyktynów. (Rysunek Jana Matejki) na s. 151. Ciciora, Katalog rysunków, nr inw. IX/1540; Kaczmarczyk, Kowalski, Katalog Archiwum Opactwa, nr kat. 132. Marian Haisig podkreślał, że pieczęć ta wraz z pieczęcią Adama kasztelana krakowskiego z roku 1257 należą do rzadkości, ponieważ właściciele przedstawieni zostali na koniach, czyli z atrybutem przynależnym wyłącznie książętom. Obie pieczęcie posiadał Bolesław Podczaszyński, Haisig, Bolesław Podczaszyński, s. 39; też Z. Piech, Pieczęć jako źródto ikonograficzne. Ze studiów nad ikonografia historyczna, „Сфрагістичний Щорічник” (Sfragìstičnij Ŝoričnik), 5 (2015) s. 51, 52.

${ }^{77}$ Pieczęć Leszka Białego przywieszona jest do dokumentu z 1228 r. przechowywanego w klasztorze w Mogile, Ciciora, Katalog rysunków; DJM, nr inw. IX/1540; Kaczmarczyk, Kowalski, Katalog Archiwum Opactwa, nr kat. 5; Żebrawski, O pieczęciach dawnej, s. 3-4, 13-15.

${ }^{78}$ Zob. przyp. 77.

${ }^{79}$ Ciciora, Katalog rysunków, nr inw. IX/1539; Kaczmarczyk, Kowalski, Katalog Archiwum Opactwa, nr kat. 15. J. Bieniak, Pakostaw Stary (Starszy), PSB, t. 25, Wrocław-Warszawa-Kraków 1980, s. 40, 41. 
mimo iż dość szczegółowo omówił je T. Żebrawski ${ }^{80}$. Co więcej, tak naprawdę nie interesowały go zagadnienia sfragistyczne, przede wszystkim nie zajmował go wygląd samych pieczęci - ani jako rzemieślniczego dzieła samego w sobie, ani w kontekście dyplomatyki - jako części dokumentu, że o braku zainteresowania samymi dokumentami zaledwie wspomnę. Doskonale to widać przy porównaniu rysunków K. Kielisińskiego i J. Matejki przedstawiających pieczęcie.

Kajetan Kielisiński przedstawiał wygląd pieczęci i wiadomości o dokumentach, do których są przywieszone, jakimi chciał dysponować historyk, sfragistyk, kolekcjoner, inwentaryzator pieczęci polskich. Istotne były zatem informacje wizualne: wygląd i stan zachowania samego odcisku pieczętnego, miseczki, wiązadeł pieczętnych (sznury, paski) łączących pieczęć z dyplomem, a ponadto dokładne odwzorowanie na rysunku napisu otokowego wraz ze skrótami łacińskich wyrazów oraz datą wystawienia dokumentu. Bardzo precyzyjnie należało pokazać na rysunku także zatarcia i ubytki pieczęci, ewentualnie na karcie papieru zapisać informacje o tym, gdzie znajduje się pieczęć, rok sporządzenia dokumentu, kolor wosku. Zatem wszelkie informacje wizualne z zakresu historii erudycyjnej, jak herby, broń, strój i inne przedmioty związane z postacią, musiały być klarownie i czytelnie przedstawione. Obiekty te mogły być zarysowane ogólnie, byle czytelna była ich funkcja (sedilie, pastorał, tiara, miecz, kolczuga, itd.). Natomiast zupełnie nie interesowały K. Kielisińskiego zagadnienia estetyczne i artystyczne. Przedstawione przez niego wizerunki pieczęci zostały potraktowane płasko, niemal graficznie, na zasadzie czarno-białych kontrastów, bez subtelnego zróżnicowania pod względem gradacji światło-cienia, co plastycznie podkreśliłoby wolumen ukazywanego przedmiotu. Nawet zaledwie rozpoczęte szkice cechuje wizja przedstawienia typowa dla grafika-ilustratora, $\mathrm{z}$ wyrazistym, mocnym konturem i światłocieniem ${ }^{81}$. Kajetan Kielisiński z reguły nie zwracał uwagi na kwestie stylistyki form poszczególnych pieczęci, szczegółów fałdowania szat, specyfiki ornamentów i detali architektonicznych.

Tymczasem J. Matejko większość tych cech albo pomija, albo nie proceduje ich systematycznie w swoich studiach pieczęci. Ma zupełnie inny cel i innego odbiorce. Rysunki przeznacza do własnych celów artystycznych i traktuje je czysto utylitarnie. Liczą sie podstawowe informacje historyczne, jak poprawne w najdrobniejszych detalach rozpoznanie kształtu przedmiotów przedstawionych na pieczęci oraz ich funkcji. Równie istotne były te elementy pieczęci, które przyciągnęły uwagę rysownika $\mathrm{w}$ trakcie studiowania obiektu, ponieważ są zapisem pomysłów, skojarzeń, które nasunęły mu się w związku z możliwością wykorzystania tych detali w kolejnych pracach artystycznych. Uwaga J. Matejki, a co za tym idzie, efekt wizualny na karcie papieru, skoncentrowana była zawsze na właścicielu pieczęci. Przede wszystkim na wizerunku postaci - domniemanym portrecie właściciela, niezwykle rzadko na herbie, a więc znaku, który reprezentuje postać ${ }^{82}$ (jak w przypadku pieczęci Leszka Białego lub wojewody Marka).

${ }^{80}$ Żebrawski, O pieczęciach dawnej, s. 5-6.

${ }^{81}$ Np. pieczęć Grzymisławy dowieszona do dokumentu z 1228 r. Por. Pokora, Album rysunków, Ao II 87.

${ }^{82} \mathrm{O}$ reprezentacji właściciela przez wizerunek na pieczęci Piech, Pieczęć jako źródło ikonograficzne, s. 28. 
Z niesłychaną wręcz determinacją J. Matejko dążył do precyzyjnego odwzorowania twarzy i stroju postaci. W tym celu podczas rysowania najpewniej używał soczewek powiększających i doświetlał odciski pieczętne. Takie działanie dematerializuje woskową, półprzejrzystą substancją odcisku, ale także - dzięki obserwacji pod różnymi kątami - pozwala prześledzić wydobyte światłem drobne, niewidoczne na pierwszy rzut oka załamania wosku ${ }^{83}$. Można obserwować i rysować $z$ dużą precyzją mimikę twarzy, załamania szat, drobne detale i ornamenty, a następnie - śledzić ich zmienność i różnorodność w różnych pieczęciach, a wreszcie - wyobrażać sobie wygląd tych ludzi i przedmiotów w naturalnych rozmiarach setki lat temu, w realnym świecie. Rekonstrukcja wyglądu postaci jest szczególnie ważna dla malarza, który jest przyzwyczajony do przedstawiania psychologicznych stanów i psychicznych przeżyć bohaterów malowanych niejednokrotnie w nadnaturalnych wymiarach. Każde draśnięcie woskowej powierzchni traktuje artysta jako pretekst do pytania, czy jest to wystarczająca i przekonująca podstawa, wskazówka do dokonania „rekonstrukcji” wyrazu twarzy? Zdarzało się, że imaginowaną postać próbował, pod wpływem skojarzenia, wyobrazić od razu na karcie papieru, tuż obok studium napieczętnego wizerunku

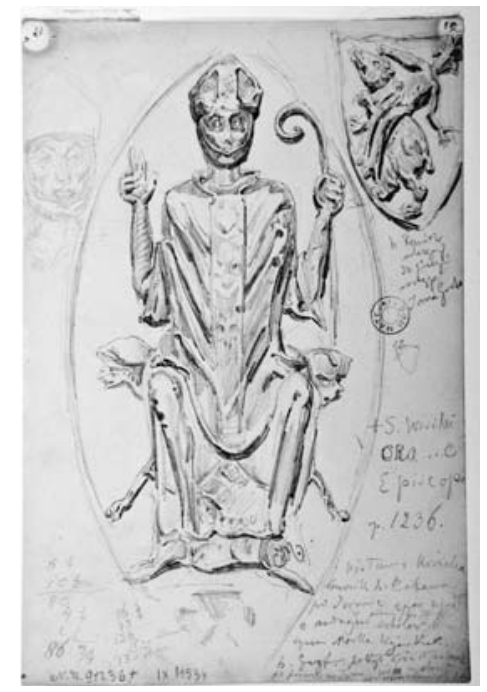

Il.3. Jan Matejko, Studium pieczęci biskupa Wisława z Kościelca, w zbiorach Muzeum Narodowego w Krakowie.

(fot. Pracownia Fotograficzna Muzeum Narodowego w Krakowie).

\footnotetext{
${ }^{83}$ To także doświadczenie autorki artykułu. Dopiero po obejrzeniu pieczęci przez szkło powiększające i doświetleniu silnym, sztucznym światłem przyjęła ona wygląd półprzezroczysty, jak na wielu rysunkach J. Matejki. Wówczas uwidocznił się w detalach jej wygląd. Taka praktyka poznawania pieczęci stoi w sprzeczności z praktyką badania pieczęci na podstawie odlewów, gdyż wówczas można zbadać jedynie ogólną ikonografię zrealizowaną na wielu odbitkach, a nie studiować i analizować szczegóły wyglądu danego egzemplarza odcisku pieczętnego. To dwa, zupełnie różne, spojrzenia na pieczęć, dostarczające odmiennych informacji: z jednej strony historycznych, czyli o znakach przeszłości, z drugiej - wizualnych, czyli o wyglądzie i ukształtowaniu znaków. Łączy je to, iż ostatecznie, wychodząc odmiennych postaw badawczych, analizują semantykę owych znaków, sumując wnioski i tworząc wiedzę na płaszczyźnie kulturowej badanego czasu.
} 
$\mathrm{Z}$ podobną uwagą i precyzją traktował narysowanie sposobu fałdowania szat, kształtów architektonicznych i ornamentalnych. W czasie, gdy naukowa refleksja nad stylistyką różnych epok artystycznych zaczynała się dopiero rozwijać, J. Matejko potrafił z bezbłędnym wyczuciem i precyzją przedstawić zróżnicowanie wspomnianych detali tak, że dziś można by podjąć się określenia stylistyki i czasu powstania realnych obiektów na podstawie jego rysunków. Jednak nie rozwój historii sztuki był celem artysty, ale wypracowanie sposobu uzyskania w jego własnych pracach malarskich i graficznych efektu „ożywienia” postaci odwzorowanych z kamiennych, woskowych czy malowanych olejno pamiątek po minionych wiekach. Wykreowanie wizji przeszłości, zrekonstruowanej na podstawie możliwie największej liczby detali minionego okresu, było celem podejmowania przez malarza studiów rysunkowych $\mathrm{w}$ zasadzie tożsamych $\mathrm{z}$ badaniami o charakterze krytycznym z zakresu nauk historycznych. Jednak materiałem badawczym były nie teksty, ale przedmioty - pieczęcie.

Podobnie jak w przypadku tekstów, charakterystyka przedmiotu dostępna była po analizie różnych cech oraz różnorodnych aspektów jego postrzegania i rozumienia. Posiadane wykształcenie wynikające z tradycji naukowej lokalnego, krakowskiego środowiska historycznego, precyzja i głębia analiz oraz uważne studiowanie wyglądu przedmiotu, a także oczekiwania odbiorcy decydowały o tym, jakie cechy i w jakim aspekcie przedstawił artysta. Aspekty i konteksty postrzegania pieczęci, coraz wnikliwiej analizowane od czasów XVII-wiecznych erudytów i XVIII-wiecznych kolekcjonerów, jak informacje o wydarzeniach, przedstawienia postaci, ich strojów, zbroi i uzbrojenia oraz otoczenia i obyczajów ${ }^{84}$, J. Matejko uzupełnił o te, typowe dla swej epoki, choć niekoniecznie popularne w środowisku krakowskim, jak stylistyka form.

Bez trudu dostrzec można, że w swych ołówkowych studiach uwzględnił te aspekty, które omówił J. Lelewel w Naukach dajacych poznawać zrzódła historyczne. Przedstawiał właścicieli pieczęci, contrasigilla (o ile miały przedstawienie antropomorficzne), notował materiał odcisku, czyli z reguły wosk i jego kolory, zwracał uwagę na kształt całej pieczęci, czy był ostroowalny, czy okrągły, starannie przerysowywał kształt niektórych liter (,scholastycznych”, jak je nazywał J. Lelewel), na koniec zaś zadbał o przerysowanie herbów oraz innych znaków ukazanych na pieczęciach. Repertuar owych znaków dobierał nie według spostrzeżeń J. Lelewela ${ }^{85}$, ale wedle własnych potrzeb wypraktykowanych podczas zdobywania materiałów ikonograficznych do Ubiorów w Polsce oraz wedle uwag T. Żebrawskiego zawartych w publikacji O pieczęciach dawnej Polski i Litwy. Zatem zwracał uwagę na: stroje, dodatki do nich, uzbrojenie i broń, sprzęty, architekturę i jej detale, ornamenty, m.in. z otoku lub pola pieczęci, kształt krzyża w otoku pieczęci. Natomiast nie zwracał uwagi na ten aspekt semantyczny średniowiecznych pieczęci, o którym pisał Sobieszczański, czyli związany z treścią napieczętnych wizerunków kościołów, herbów, różnego rodzaju godeł, gryfów

${ }^{84}$ Pomian, Zbieracze i osobliwości, s. 156-160.

${ }^{85}$ Joachim Lelewel pisał o „dawnych znakach rozmaitych na pieczęciach używanych”, obok których na pieczęciach zaczynają się pojawiać herby. Lelewel, Nauki, s. 41. 
i bestii, aniołów w funkcji trzymaczy, itp ${ }^{86}$. Świat średniowiecznych mitycznych wyobrażeń, zakorzenionych w pogaństwie wierzeń i desygnatów władzy nie interesował go. Interesowała go HISTORIA i rozważając jej problematykę kreował przedstawienia polskich dziejów. Dla realizacji tego celu przeglądał skarbce polskiej kultury.

Refleksje F. Sobieszczańskiego oraz T. Żebrawskiego, traktujące o pieczęciach w kategoriach historii erudycyjnej i kultury materialnej oraz w kategoriach sztuk wizualnych, były bliskie celom i potrzebom J. Matejki jako artysty, a szczególnie malarza historycznego. Skorzystał zatem z porady T. Żebrawskiego - używania pieczęci do datowania przedstawionych na nich obiektów. Franciszek Sobieszczański i w ślad za T. Żebrawskim także J. Matejko byli świadomi tego, że jeśli spojrzeć na pieczęcie nie tylko w kontekście historycznym, ale także artystycznym, to charakteryzuje je także ,smak i stopień [poziom - BC] sztuki"87. Ów „smak”, dziś określany m.in. jako styl ${ }^{88}$, J. Matejko znacznie trafniej potrafił dostrzec i scharakteryzować wizualnie, niż krakowscy amatorzy dokształcający się w zakresie historii sztuki, ponieważ wykonując ołówkowe studia wielu rzeczywistych zabytków poznawał je szczegół po szczególe, a w tym także - specyficzne dla danej epoki - kształtowanie stylistyczne formy. Znając czas powstania danego zabytku, artysta był w stanie powiązać z nim ,smak”, czyli formułę stylistyczną, dominującą w tym okresie czasu. Z kolei F. Sobieszczański, wrażliwy plastycznie $\mathrm{i}$ bardzo dobrze wykształcony $\mathrm{w}$ tym zakresie ${ }^{89}$, precyzyjnie definiował te walory pieczęci:

Pod względem sztuki żaden może oddział rzeźby tak dokładnego o jej postępie nie daje wyobrażenia co pieczęcie; symboliczna i charakterystyczna ich rozmaitość, ulepszenie ich ozdób, delikatność wyrobu w tych pracach, często w zadziwienie wprawia. Stąd też znakomitą one mają od monet wyższość, już to iż są obszerniejsze, już iż więcej artystyczności w nich spostrzegać się daje ${ }^{90}$.

Janowi Matejce udawało się czasem oddać ową ,artystyczność”, ów „stopień sztuki”, jeśli tylko pieczęcie, które rysował, zachowały się w dobrym stanie.

${ }^{86}$ Sobieszczański, Wiadomości historyczne, s. 185.

${ }^{87}$ Żebrawski, O pieczęciach dawnej, s. 3.

${ }^{88}$ W. Bałus, Renesans $w$ wieku XIX $i$ XX: fascynacja i sprzeciw, w: Recepcja renesansu w XIX i XX wieku. Materiały Sesji Stowarzyszenia Historyków Sztuki, Łódź, listopad 2002, Łodź 2003, s. 22.

${ }^{89}$ Franciszek Maksymilian Sobieszczański był samoukiem, choć słuchał wykładów uniwersyteckich z zakresu historii sztuki i archeologii. Biogram pióra Wincentego Korotyńskiego w „Tygodniku Ilustrowanym", (1878) nr 128, s. 354.

${ }^{90}$ Sobieszczański, Wiadomości historyczne, t. 1, s. 182. 


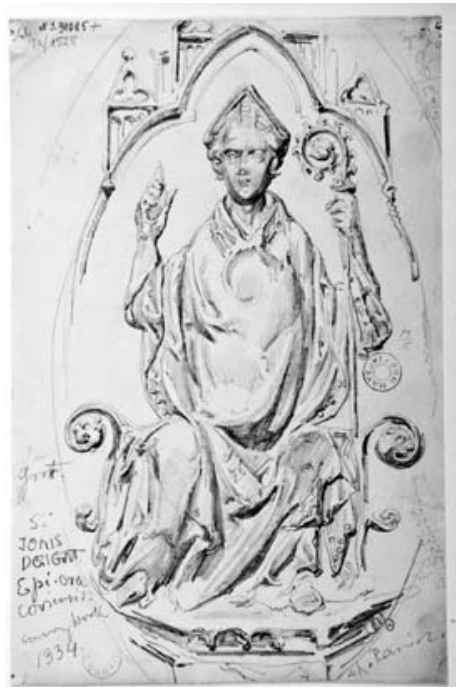

Il.4. Jan Matejko, Studium pieczęci biskupa Jana Grotowic, w zbiorach Muzeum Narodowego w Krakowie.

(Fot. Pracownia Fotograficzna Muzeum Narodowego w Krakowie)

Jakkolwiek artysta umiał posługiwać się stylistyką, nie ona była jego celem. Nie intrygowało go śledzenie meandrów późnośredniowiecznych fałdów szat, zaznaczał je, ale nie na nich koncentrował uwagę. Zresztą, często były tak silnie zatarte, zniszczone i zdeformowane, że nie można było w półprzezroczystej masie woskowej dopatrzyć się ich delikatnie zarysowanego duktu. Natomiast można było dojrzeć stylistykę i dekorację architektoniczną oraz ornamenty, a zatem zagadnienia znane architektom i budowniczym krakowskim już ok. 1860 roku dzięki ich działalności konserwatorskiej. Niezwykle rzadko, ale zdarzało się w przypadku bardzo zatartych pieczęci, że J. Matejko koncentrował się na ich walorach plastycznych tak, jak na walorach malowanego lub płaskorzeźbionego obrazu, czyli na grze linii i kontrastowo potraktowanych plam światłocienia, natomiast z pominięciem zaznaczenia wolumenu przedstawionych przedmiotów oraz - typowej dla artysty - chęci rekonstrukcji przeszłości, także w jej psychologicznym ujęciu ${ }^{91}$.

W Matejkowskich studiach pieczęci uderza widza niedokończenie wielu partii rysowanych pieczęci, ukazanie połowy ich wizerunku, a nawet fragmentów, np. zaledwie wyrazu lub kilku liter $\mathrm{z}$ napisu $\mathrm{w}$ otoku pieczęci narysowanych $\mathrm{w}$ dokładnie takim kroju, jak na pieczęci, podczas gdy reszta została zapisana zwykłym pismem. Podobnie $\mathrm{z}$ architekturą. Jeśli była podobna po obu stronach osi symetrii przedstawienia na pieczęci, malarz przedstawiał precyzyjnie tylko jedną jej połowę.

${ }^{91}$ Zob. rysunki pieczęci Oleśnickiego i klasztoru klarysek, DJM, nr inw., IX/1520 i pieczęci kapituły płockiej, DJM, nr inw. IX/1538. 


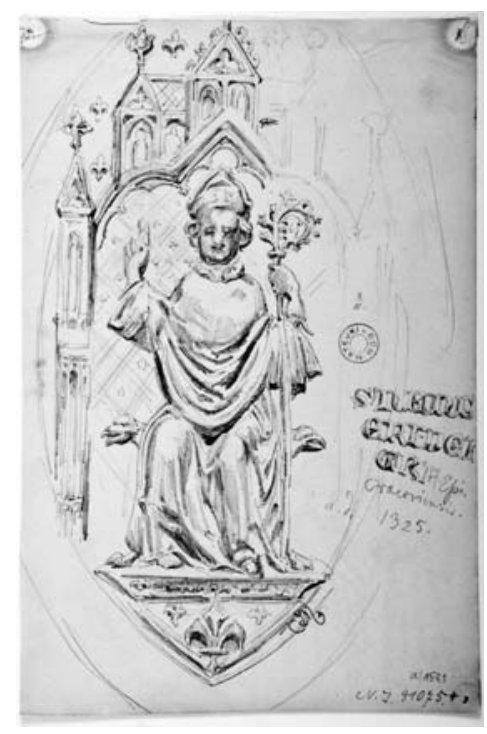

Il. 5. Jan Matejko, Studium pieczęci biskupa Nankera, w zbiorach Muzeum Narodowego w Krakowie.

(Fot. Pracownia Fotograficzna Muzeum Narodowego w Krakowie).

Należy pamiętać o celu rysunków — były materiałem pomocniczym dla samego artysty. Rysowanie całości napisu literami „scholastycznymi” czy całej architektury nie było mu potrzebne, ponieważ wizerunek całego obiektu lub całego napisu przedstawiał na rysunku z finalną kompozycją, przeznaczonym pod drzeworyt albo do namalowania na obrazie. Na herby zwracał uwagę rzadko, chyba że zainteresował go kształt lub przedstawiona akcja, jak w herbie Rawicz, na którym kobieta jedzie wierzchem na niedźwiedziu damskim sposobem. Trzy włócznie w herbie Jelita Floriana z Morska wykorzystał jako motyw dekoracyjny na ścianie za plecami biskupa przedstawionego na drzeworycie. Podobnie potraktował znak krzyża rozpoczynający napis $\mathrm{w}$ otoku pieczęci. 

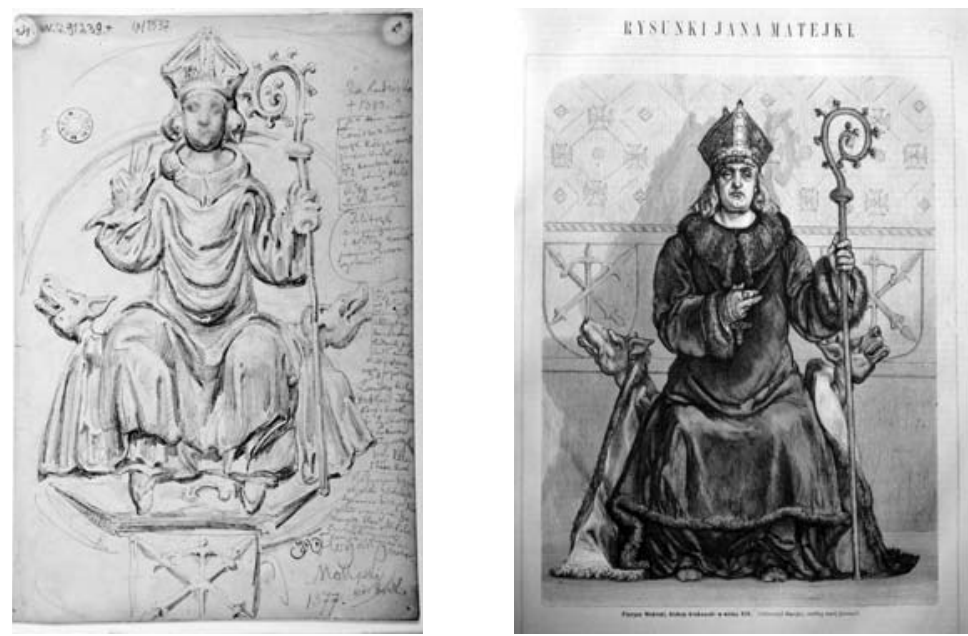

Il. 6-7, Jan Matejko, Studium pieczęci Floriana z Mokrska, w zbiorach Muzeum Narodowego w Krakowie. Fot. Pracownia Fotograficzna Muzeum Narodowego w Krakowie / Jan Schübeler według rysunku Jana Matejki, drzeworyt ilustrowany, zatytułowany: Rysunki Jana Matejki. Flory-

an Mokrski, biskup krakowski w wieku XIV. (Odtworzył Matejko, wedlug starej pieczęci), „Tygodnik Ilustrowany”, 1871

Potrzebował detalu, precyzyjnie ukazanego elementu, by wykorzystać go w nowo wykreowanej pracy, np. grafice ilustracyjnej w warszawskim tygodniku. Każdy element pieczęci mógł zmienić swe pierwotne znaczenie i stać się desygnatem innego znaczenia, oznaczającym już nie tylko funkcję użytkową, ale idee swojego czasu, wieków XII, XIII lub XIV.

Podsumowując, K. Kielisiński inwentaryzował, ukazując odcisk pieczęci, powtarzalny, wspólny wszystkim odciskom z jednego tłoku, natomiast J. Matejko studiował przedmiot ze wszelkimi jego walorami, wyjątkami, obocznościami. Kajetan Kielisiński operował zatem znakiem - komunikatem, a nie, jak J. Matejko, realnym, wyjątkowym przedmiotem z całą gamą aspektów historycznych i plastycznych, a także - artystycznych, których nauczano młodych adeptów sztuki w akademiach sztuk pięknych. Kajetan Kielisiński studiując pieczęć, dążył do narysowania finalnego efektu swej pracy, na podstawie którego wykona graficzną odbitkę. Jan Matejko rysunki sporządzone w mogilskim archiwum zamierzał dopiero wykorzystać do artystycznej kreacji, czyli stworzenia postaci i znaków w kolejnych, ukończonych pracach - w dopracowanych kompozycjach rysunkowych, przygotowanych pod drzeworyty, w obrazach olejnych, w projektach. W świetle przedstawionych powyżej ustaleń można stwierdzić, że studia J. Matejki mają charakter badawczy, krytyczny, o cechach refleksji historycznej, a nie odtwórczy, inwentaryzatorski, jak Kajetana Kielisińskiego. Każdy rysunek stanowi efekt połączenia wiedzy historycznej z przenikliwą obserwacją realnych pamiątek przeszłości. To właśnie czyni Matejkowskie studia wyjątkowymi na tle wysiłków podejmowanych przez innych malarzy historycznych w zakresie pozyskiwania rekwizytów przedstawianych w swych pracach. 
Porównując efekty rysowniczej pracy K. Kielisińskiego i J. Matejki widać nie tylko różnice celów, ale także koncepcji przedstawienia. Kajetan Kielisiński obrazował cele kolekcjonerów, dawał obraz „pamiątki” czy też dokumentu źródłowego. Tymczasem J. Matejko dążył konsekwentnie do odtworzenia obrazu przeszłości. Studia pieczęci były tylko jednym z etapów realizacji tego celu. Z okruchów przeszłości - fragmentarycznych studiów tak drobnych jej świadectw, jak pieczęcie - budował pracowicie wizję wyglądu całości. Na aspekcie wizualnym bynajmniej nie poprzestawał, co widać po rekonstrukcjach na kartach rysunków, uwzględniał też psychikę postaci, ponieważ i ona miała wpływ na wydarzenia. Ostatecznie, wszystkie działania artysty służyły budowaniu dzieła sztuki, by poprzez nie i dzięki niemu tworzyć wizualny model historii oraz malarstwa historycznego, satysfakcjonującego zarówno w płaszczyźnie wizualnej, jak $i$ anegdotycznej oraz historiozoficznej.

\section{BIBLIOGRAFIA}

\section{Źródła}

Archiwum Narodowe w Krakowie

sygn. E 17, Teki Grabowskiego.

Biblioteka Jagiellońska

sygn. 11060 IV, Odpisy korespondencji i listów Gwalberta Pawlikowskiego

Biblioteka Polskiej Akademii Nauk i Polskiej Akademii Umiejętności w Krakowie,

sygn. 1488, t. 6, Wstęp do Katalogu wystawy starożytności narodowych, urządzonej w Krakowie w r. 1858, składka Pieczęcie na wosku wytłoczone (wszystkie ze zbioru p. Mieczysława Pawlikowskiego)

sygn. 369 7, Księga darów 1859-1871

sygn. 3697 Księga darów 1859-1871

Diplomata monasterii clarae tumbae prope Cracoviam. Zbiór dyplomatów klasztoru mogilskiego przy Krakowie, Kraków 1865

Kodeks dyplomatyczny Wielkiej Polski, Poznań 1840 wydany przez Edwarda Raczyńskiego

Lites ac Res gestae inter Polonos Ordinemque Cruciferorum, wyd. Tytus Działyński, T. 1 i 2, Posnaniae 1855, T. 3 Posnaniae 1856

Zbiór praw litewskich od roku 1389. do roku 1529 tudzież rozprawy sejmowe o tychże prawach od roku 1544. do roku 1563., red. Adam Tytus Działyński, Poznań 1841.

Zbiór praw litewskich od roku 1389. do roku 1529 tudzież rozprawy sejmowe o tychże prawach od roku 1544. do roku 1563., red. Adam Tytus Działyński, Poznań 1841.

\section{Opracowania}

Bałus Wojciech, Renesans w wieku XIX i XX: fascynacja i sprzeciw, w: Recepcja renesansu w XIX i XX wieku. Materialy Sesji Stowarzyszenia Historyków Sztuki, Łódź, listopad 2002, Łodź 2003, s. 11-33

Beyer Karol, Album fotograficzne wystawy starożytności i zabytków sztuki urzadzonej przez C.K. Towarzystwo Naukowe Krakowskie w Krakowie 1858 i 1859 r., Warszawa [1859]. 
Bieniak Janusz, Pakosław Stary (Starszy), w: Polski Stownik Biograficzny, t. 25, Wrocław-Warszawa-Kraków 1980, s. 38-42.

Bieńkowski Wiesław, Matejko Franciszek Ksawery Edward, w: Polski Słownik Biograficzny, t. 20, Wrocław-Warszawa-Kraków 1975, s. 183-184.

Ciciora Barbara, Matejko a średniowiecze. Zainteresowania-inspiracje-realizacje, Kraków 2009, mps, rozprawa doktorska napisana pod kierunkiem prof. dra hab. Wojciecha Bałusa w Instytucie Historii Sztuki Uniwersytetu Jagiellońskiego, Archiwum Uniwersytetu Jagiellońskiego, sygn. 2009/095.

Ciciora Barbara, Katalogu rysunków Jana Matejki w zbiorach Muzeum Narodowego $w$ Krakowie. Cz. 1. Studia z natury (w druku).

Czacki Tadeusz, O Litewskich i Polskich prawach o ich duchu, źródtach, zwiazku, i o rzeczach zawartych w pierwszym Statucie dla Litwy 1529 roku wydanym, Kraków 1861.

Danowska Ewa, Tadeusz Czacki 1765-1813. Na pograniczu epok i ziem, Kraków 2006.

Dębicki Ludwik, Puławy, t. 2, Lwów 1887.

Doniesienia Literackie, „Biblioteka Warszawska”, 3 (1850) s. 574-575.

Dybiec Julian, Michat Wiszniewski jako profesor historii powszechnej w Uniwersytecie Jagiellońskim, „Kwartalnik Historii Nauki i Techniki”, 9 (1964) nr 2, s. 211-227.

Eye A. von, Falke Jacob von, Kunst und Leben der Vorzeit von Beginn des Mittelalters bis zu Anfang des 19. Jahrhundets, Nürnberg 1858, Bd. 1, b.n.s

Gieysztor Aleksander, Nauki dające poznawać źródła historyczne w Uniwersytecie Warszawskim, w: Tradycje i perspektywy nauk pomocniczych historii w Polsce. Materiaty z sympozjum w Uniwersytecie Jagiellońskim dnia 21-22 października 1993 roku, red. M. Rokosz, Kraków 1995, s. 29-33.

Grabski Andrzej, Dzieje historiografii, Poznań 2006.

Gumowski Marian, Haisig Marian, Mikucki Sylwiusz, Sfragistyka, Warszawa 1960.

Haisig Marian, Bolesław Podczaszyński. Sfragistyk i archeolog, Wrocław 1952.

Hanik Jan, Rosnowska Janina, Pol Wincenty, w: Polski Stownik Biograficzny, t. 27, Wrocław-Warszawa-Kraków 1983, s. 255-263.

Jabłoński-Pawłowicz Izydor, Wspomnienia o Janie Matejce, Lwów 1912.

Kaczmarczyk Kazimierz, Kowalski Gerard, Katalog Archiwum Opactwa OO. Cystersów w Mogile, Kraków-Mogiła 1919.

Kraszewski Józef Ignacy, Listy do Redakcji Gazety Warszawskiej, „Gazeta Warszawska”, (1853) Nr 205, s. 4.

Kraszewski Józef Ignacy, Listy do Redakcji Gazety Warszawskiej, „Dodatek” do „Gazety Warszawskiej", (1853) Nr 208, s. 6-7.

Kuczyński Stefan Krzysztof, Kazimierz Stronczyński jako sfragistyk i heraldyk, w: Kazimierz Stronczyński. Numizmatyk, sfragistyk i inwentaryzator zabytków. Materiały sesji naukowej, Piotrków Trybunalski 1983, s. 23-37.

Kuczyński Stefan Krzysztof, Początki polskich badań sfragistycznych na tle europejskim, w: Pieczęcie w dawnej Rzeczypospolitej. Stan i perspektywy badań, red. Z. Piech, J. Pakulski, J. Wroniszewski, Warszawa 2006.

Lelewel Joachim, Nauki dajace poznawać źrzódła historyczne, Poznań 1863.

Lites ac Res gestae inter Polonos Ordinemque Cruciferorum, wyd. T. Działyński, t. 1 i 2 , Posnaniae 1855, t. 3 Posnaniae 1856.

Maciejewski Janusz, Przedburzowcy. Z problematyki przełomu między romantyzmem a pozytwizmem, Kraków 1971.

Matejko Franciszek, Jerzy Juliusz Klowio, miniaturzysta chorwacki (Ur. 1498, +1578), „Tygodnik Ilustrowany”, (1865) nr 294, s. 173-174. 
Mikucki Sylwiusz, Nauki pomocnicze historii w Uniwersytecie Jagiellońskim, w: Studia $z$ dziejów Wydziału Filozoficzno-Historycznego Uniwersytetu Jagiellońskiego, red. S. Mikucki, Kraków 1967, s. 153-183.

Mossakowska Wanda, Fotografia przyjaciót Artura Grottgera i Walerego Rzewuskiego z 1865 roku, w: Fotografia. Od dagerotypu do Galerii Hybrydy. Materiaty z sesji naukowej zorganizowanej przez Oddział Warszawski Stowarzyszenia Historyków Sztuki, red. D. Jackiewicz, Z. Jurkowlaniec, Warszawa 2008, s. 32-45.

Orańska Józefa, Kajetan Wincenty Kielisiński w świetle dokumentów i prac w zbiorach kórnickich, Kórnik 1947.

Piech Zenon, Zbiory pieczęci jako przedmiot badań sfragistycznych w: Zbiory pieczęci w Polsce, red. Z. Piech i W. Strzyżewski, Warszawa 2009, s. 7-30.

Piech Zenon, Pieczęć jako źródło ikonograficzne. Ze studiów nad ikonografia historyczna, „Sfragìstičnij Ŝrorǐnik”, 5 (2015) s. 21-87.

Piekosiński Franciszek, Pieczęcie polskie wieków średnich. Część 1. Doba piastowska, Kraków 1899.

Perzanowski Zbigniew, Z dziejów Zakładu Nauk Pomocniczych Historii i Archiwistyki $w$ Uniwersytecie Jagiellońskim, w: Tradycje i perspektywy nauk pomocniczych historii $w$ Polsce. Materiały z sympozjum w Uniwersytecie Jagiellońskim dnia 21-22 października 1993 roku, red. M. Rokosz, Kraków 1995, s. 21-27.

Pokora Piotr, Rysunki pieczęci Kajetana Wincentego Kielisińskiego w zbiorach Biblioteki PAN w Kórniku w: Zbiory pieczęci w Polsce, red. Z. Piech, W. Strzyżewski, Warszawa 2009, s. 377-476.

Pokora Piotr, Album rysunków pieczęci Kajetana Wincentego Kielisińskiego ze zbiorów Biblioteki Kórnickiej Polskiej Akademii Nauk, Kórnik 2013.

Pol Wincenty, O malarstwie $i$ żywiołach jego w kraju naszym, „Tygodnik Literacki literaturze, sztukom pięknym i krytyce poświęcony”, (1839) nr 24, s. 186-187.

Polanowska Jolanta, Oleszczyński Antoni, biogram, w: Słownik Artystów Polskich, t. 6, Warszawa 1998, s. 242-250.

Pomian Krzysztof, Zbieracze i osobliwości. Paryż-Wenecja, XVI-XVIII wiek, Gdańsk 2012.

Schnaydrowa Bogumiła, Z dziejów krakowskiej Wystawy Starożytności, ,Rocznik Biblioteki PAN w Krakowie", 23 (1977) s. 131-151.

Secomska Krystyna, Spór o starożytność. Problemy malarstwa w „Paralelach” Perrault, Warszawa 1991.

Serafińska Stanisława, Jan Matejko. Wspomnienia rodzinne, wyd. 2, Kraków 1958.

Seredyński Hipolit, Uposażenie klasztoru cystersów w Mogile, w: Monografia opactwa Cystersów we wsi Mogile, Kraków 1867, s. 73-86.

Sobieszczański Franciszek Maksymilian, Wiadomości historyczne o sztukach pięknych w dawnej Polsce, t. 1, Warszawa 1847.

Starzyński Marcin, Herby średniowiecznych opatów mogilskich, Kraków 2005.

Stronczyński Kazimierz, Wzory pism dawnych $w$ przerysach wystawione i objaśnione drukowanem ich wyczytaniem, Cz. 1. obejmujaca pismo dyplomatów od roku 1228 do 1536, Warszawa 1839.

Szujski Józef, Wiadomość historyczna o Mogile, w: Monografia opactwa Cystersów we wsi Mogile, Kraków 1867, s. 5-24.

Szymański Józef, Sto lat przemian metodologicznych nauk pomocniczych historii w Polsce, w: Tradycje i perspektywy nauk pomocniczych historii w Polsce. Materiaty z sympozjum $w$ Uniwersytecie Jagiellońskim dnia 21-22 października 1993 roku, red. M. Rokosz, Kraków 1995, s. 35-47.

Unger Józef, Prospekt „Tygodnika Ilustrowanego”, 20 sierpnia 1859 roku, b.n.s. 
Vossberg Friedrich August, Siegel des Mittelalters von Polen, Lithauen, Schlesien, Pommern und Preussen. Ein Beitrag zuf Förderung diplomatischer, genealogischer, numismatischer und Kunstgeschichtlicher Studien über ursprunglich Slavische Theile der Preussischen Monarchie, Berlin 1854.

Żebrawski Teofil, O pieczęciach dawnej Polski i Litwy, Kraków 1865.

Żygulski Zdzisław, Dzieje zbiorów puławskich (Świątynia Sybilli i Dom Gotycki), „Rozprawy i Sprawozdania Muzeum Narodowego w Krakowie", 2 (1962) s. 5-256.

Żygulski Zdzisław, Muzea na świecie. Wstęp do muzealnictwa, Warszawa 1982

\title{
Netografia
}

Teofil Żebrawski, http://tnk.krakow.pl/czlonkowie/zebrawski-teofil/ (dostęp: 04.07.2019).

\begin{abstract}
ANEKS
Franciszek Piekosiński wskazał w zbiorach Pawlikowskich w Medyce pieczęć Konrada Mazowieckiego pochodzącą z archiwum mogilskiego:

Egzemplarz uszkodzony wisiał u dokumentu z r. 1223 w arch. Cystersów w Mogile i tento egzemplarz, dziś oderwany, przechowywany jest w zbiorach Pawlikowskiego we Lwowie. $Z$ tego to egzemplarza pochodzi sztych C. E. Webera u Vossberga na tabl. $16^{92}$.
\end{abstract}

Świetne przykłady średniowiecznych pieczęci królewskich i książęcych należących do jego kolekcji można obejrzeć na zdjęciach Karola Beyera opublikowanych w: Karol Beyer, Album fotograficzne wystawy starożytności i zabytków sztuki urzadzonej przez C.K. Towarzystwo Naukowe Krakowskie w Krakowie 1858 i 1859 r., Warszawa [1859], Tab. LXXIV i LXXV; spis wszystkich pieczęci wypożyczonych przez Pawlikowskich na wystawę, zob. BPAU/PAN, sygn. 1488, t. 6, Wstęp do Katalogu wystawy starożytności narodowych, urządzonej w Krakowie w r. 1858, składka Pieczęcie na wosku wyttoczone..., k. 1-68. Teofil Żebrawski wskazał ponadto pieczęć Leszka Czarnego, która była przywieszona do dokumentu w klasztorze mogilskim jeszcze w latach 30. XIX wieku, gdy rysował ją Kajetan Kielisiński, a potem na podstawie rysunku wykonał grafikę;

Ryta przez Kielisińskiego jest na tabl. 4 dzieła Vossberga; wisiała niegdyś na sznurku z piusowego i żółtego jedwabiu u dyplomu Leszka Czarnego z 1286 r. w klasztorze XX. Cystersów w Mogile; dziś znajduje się oderżnięta we Lwowie, w zbiorze po Gw.[albercie] Pawlikowskim ${ }^{93}$.

Część pieczęci odciętych od dokumentów cysterskich w Mogile znalazło się wśród pieczęci luźnych w Bibliotece XX. Czartoryskich, P. Pokora, Rysunki pie-

${ }^{92}$ F. Piekosiński, Pieczęcie polskie wieków średnich. Część 1. Doba piastowska, Kraków 1899, s. 60 , nr 54, Fig. 46

${ }^{93}$ Żebrawski, O pieczęciach dawnej, s. 27, nr 14 i 15; była wypożyczona na Wystawę Starożytności w 1858 roku, por. BPAU/PAN, sygn. 1488, t. 6, Wstęp do Katalogu wystawy starożytności, t. 6 , nr kat. 1678, k. 38 . 
częci Kajetana Wincentego Kielisińskiego w zbiorach Biblioteki PAN w Kórniku, w: Zbiory pieczęci w Polsce, red. Z. Piech, W. Strzyżewski, Warszawa 2009, s. 380 .

Los niektórych pieczęci z archiwum w Mogile można prześledzić, porównując rysunki i grafiki wykonane przez K. Kielisińskiego, noty katalogowe T. Żebrawskiego do katalogu Wystawy Starożytności (1858) na temat pieczęci wypożyczonych na Wystawę Starożytności przez Pawlikowskich ze zbiorów w Medyce oraz katalog mogilskiego archiwum opublikowany przez Kazimierza Kaczmarczyka i Gerarda Kowalskiego OC w 1919 roku. K. Kielisiński ilustrował pieczęć, podawał miejsce wykonania rysunku pieczęci, np. archiwum w Mogile, datę wystawienia dokumentu, do którego była przywieszona i często dodatkowe informacje, np. wymiary, kolor wosku, itp. T. Żebrawski bardzo lakonicznie wzmiankuje rozmiary lub kształt pieczęci, kolor wosku i przytacza napis w otoku; czasem podaje datę wystawienia dokumentu, do którego przywieszona była dawniej pieczęć. K. Kaczmarczyk i G. Kowalski publikowali dane katalogowe na temat dokumentu, krótką informację o jego treści oraz informacje o stanie zachowania istniejących pieczęci i o tym, które zostały odcięte od dokumentu. Porównanie ilustracji K. Kielisińskiego z informacjami podanymi przez T. Żebrawskiego oraz przez K. Kaczmarczyka i G. Kowalskiego pozwala wskazać kilka kolejnych pieczęci z Mogiły pozyskanych przez G. Pawlikowskiego do własnych zbiorów, prawdopodobnie dzięki działalności dokumentacyjnej K. Kielisińskiego. Były to: pieczęć konna Konrada Mazowieckiego, której brak przy dokumencie z 1223 r. (BPAU/ PAN, sygn. 1488, t. 6, Wstęp do Katalogu Wystawy Starożytności, nr kat. 1623, s. 31, P. Pokora, Album rysunków pieczęci Kajetana Wincentego Kielisińskiego ze zbiorów Biblioteki Kórnickiej Polskiej Akademii Nauk, Kórnik 2013, sygn. Ao II 84, K. Kaczmarczyk, G. Kowalski, Katalog Archiwum Opactwa OO. Cystersów w Mogile, Kraków-Mogiła 1919, nr kat. 3, s. 2), pieczęć Leszka Czarnego ze św. Stanisławem (BPAU/PAN, sygn. 1488, t. 6, Wstęp do Katalogu wystawy starożytności, nr kat. 1678, k. 38, Pokora, Album rysunków, sygn. Ao II 120, Kaczmarczyk, Kowalski, Katalog Archiwum Opactwa, nr kat. 36, s. 12), pieczęć Władysława I, księcia oświęcimskiego (BPAU/PAN, sygn. 1488, t. 6, Wstęp do Katalogu wystawy starożytności, nr kat. 1661, k. 63, Pokora, Album rysunków, sygn. Ao II 165, Kaczmarczyk, Kowalski, Katalog Archiwum Opactwa, nr kat. 51, s. 17), dwie pieczęcie mniejsze Kazimierza Wielkiego (BPAU/PAN, sygn. 1488 , t. 6, Wstęp do Katalogu wystawy starożytności, nr kat. 1650, k. 25 oraz nr kat. 1668, k. 24; Pokora, Album rysunków, sygn. Ao I 99; Kaczmarczyk, Kowalski, Katalog Archiwum Opactwa, nr kat. 86, s. 29, nr kat. 89, s. 30). Warto zwrócić uwagę na różnice pomiędzy rysunkiem K. Kielisińskiego, a informacjami K. Kaczmarczyka i G. Kowalskiego. Rysownik przedstawił pieczęcie Kazimierza Wielkiego zawieszone na sznurach (Pokora, Album rysunków, sygn. Ao II 9), podczas gdy autorzy katalogu, historyk i archiwista zanotowali, iż pieczecie były przywieszone na pergaminowych paskach; o dokumencie z 1353 roku piszą: „Pieczęci brak, pozostały perg. paski równo ucięte”, Kaczmarczyk, Kowalski, Katalog Archiwum Opactwa, nr kat. 86, s. 29; o dokumencie z 1356 roku natomiast: „Po pieczęci zawieszonej na pasku perg. pozostała tylko osłona $\mathrm{z}$ wosku 
bez wycisku", tamże, nr kat. 89, s. 30). Ten sam los podzieliła pieczęć konna Bolesława Wstydliwego (BPAU/PAN, sygn. 1488, t. 6, Wstęp do Katalogu wystawy starożytności, nr kat. 1647, k. 9; Pokora, Album rysunków, sygn. Ao II 99; Kaczmarczyk, Kowalski, Katalog Archiwum Opactwa, nr kat. 18, s. 6). Odnośnie do wiarygodności informacji K. Kielisińskiego o tej pieczęci wątpliwości miał Piotr Pokora: „Kielisiński błędnie datował rysunek pieczęci, gdyż jej oryginał zachował się przy dokumencie z 1244 r.", Pokora, Album rysunków, nr kat. Ao II 99. To prawda, że oryginał pieczęci zachował się przy dokumencie z 1244 roku, ale prawdą jest także informacja autorów katalogu archiwum, że przy dokumencie z 1243 roku, wystawionym przez Bolesława, syna Leszka, księcia Polski, brak pieczęci wystawcy oraz dwóch innych pieczęci - Kaczmarczyk, Kowalski, $\mathrm{Ka}$ talog Archiwum Opactwa, nr kat. 18, s. 6, pieczęć zaś księcia Bolesława, odcięta od dokumentu, została przysłana w 1858 roku do Krakowa na Wystawę Starożytności, jako własność Pawlikowskich w Medyce, (BPAU/PAN), sygn. 1488, t. 6, Wstęp do Katalogu wystawy starożytności, nr kat. 1647, k. 9).

Faktu posiadania przez Pawlikowskich pieczęci pochodzących z archiwum klasztornego w Mogile byli świadomi także autorzy katalogu archiwum, którzy o pieczęciach odciętych od najstarszego dokumentu z 1220 roku napisali:

Pieczęci było pierwotnie pięć [...] Po czwartej i piątej pieczęci Budziwoja i Mikołaja znajdujących się obecnie w bibliotece Pawlikowskich we Lwowie, pozostały nacięcia ${ }^{94}$.

Wspominał o tym również, jak wyżej zaznaczono, F. Piekosiński pisząc o pieczęci Konrada, księcia mazowieckiego:

Egzemplarz uszkodzony wisiał u dokumentu z r. 1223 w arch. Cystersów w Mogile i tento egzemplarz, dziś oderwany, przechowywany jest w zbiorach Pawlikowskiego we Lwowie. $Z$ tego to egzemplarza pochodzi sztych C.E. Webera u Vossberga na tabl. 16. S. 61: Z bardzo uszkodzonego egzemplarza wiszącego u dokumentu z r. 1223, wykonał sztych Kielisiński, który jest zamieszczony w Działyńskiego Lites... tom I, na karcie tytułowej ${ }^{95}$.

Franciszek Pawlikowski pozyskiwał też pieczęcie drogą kupna, por. odpis listu Karola Beyera do Gwalberta Pawlikowskiego napisanego w Warszawie, w dniu 15 maja 1850 r., Biblioteka Jagiellońska, Odpisy korespondencji i listów Gwalberta Pawlikowskiego, sygn. 11060 IV.

\footnotetext{
${ }^{94}$ Kaczmarczyk, Kowalski, Katalog Archiwum Opactwa, nr kat. 1, s. 1.

${ }^{95}$ Piekosiński, Pieczęcie polskie, s. 60, nr 54, Fig. 46.
} 


\title{
MATEJKO'S STUDIES ON SEALS KEPT IN THE MONASTERY ARCHIVES IN MOGILA. ORIGIN
}

\begin{abstract}
Summary
Jan Matejko's drawings depicting seals stored in the Archives of the Cistercian Monastery in Mogiła reflect the state of historical awareness, the cultural needs of Poles in the 19th century and the model of historicism developed in Galicia in the mid-19th century. They are a testimony to the Polish reception of 17th century erudite historiography, which, as a sign of local patriotism, ascribed value to the local heritage of material culture and included it in the concept of world history, and, in the 19th century, also in the concept of national and world history of civilisation. The analyses are based on historiographic, collectors' and cultural views shaping the activities and artistic excellence of the historical painter in the 19th century. The views that might have affected Jan Matejko's perception of the seal were highlighted. A key role in this process is played by the issues of broadening the semantic field of objects produced in the past centuries, which, at the beginning of the 19th century, were given the status of a souvenir and were willingly collected together, and which at the same time, like seals, constituted a source of historical knowledge understood in an erudite way, i.e. not only as a carrier of information about dates, characters and events, but also about clothes, militaries, material culture and customs, which in the 19th century became an object of interest for historical painters.

Analyses of Jan Matejko's drawings reveal the vastness of perception of single medieval seals also in terms of aesthetics, art and style, since the painter's ultimate goal was not only to reconstruct the appearance of the seal, but also a historical reconstruction and historiosophical evaluation of the past. The differences between the inventory-oriented perception of seal images and the perception summing up the above mentioned determinants of the artist's work with an artistic, individualised type of his creative expression have been emphasized, which in the case of Jan Matejko's studies has additionally acquired the adopted of analytical research on seals as visual fragments of historical sources.
\end{abstract}

Keywords: Jan Matejko; drawing; stamp drawings; sphragistics; historical painting; 19th century collections 